Article

\title{
Initial Characterization and Water Quality Assessment of Stream Landscapes in Northern Mongolia
}

\author{
Jürgen Hofmann ${ }^{1, *}$, Daniel Karthe ${ }^{2}$, Ralf Ibisch ${ }^{2}$, Michael Schäffer ${ }^{2}$, Saulyegul Avlyush ${ }^{3}$, \\ Sonja Heldt ${ }^{4}$ and Andrew Kaus ${ }^{2}$
}

1 Department Ecohydrology, Leibniz Institute of Freshwater Ecology and Inland Fisheries (IGB), Müggelseedamm 310, Berlin D-12587, Germany

2 Department Aquatic Ecosystems Analysis and Management (ASAM), Helmholtz Centre for Environmental Research (UFZ), Brückstrasse 3a, Magdeburg D-39114, Germany;

E-Mails: daniel.karthe@ufz.de (D.K.); ralf.ibisch@ufz.de (R.I.); michael.schaeffer@ufz.de (M.S.); andrew.kaus@ufz.de (A.K.)

3 Institute of Geography-Geoecology (Ecological Department), Mongolian Academy of Sciences; Baruun Selbe-15, Chingeltei District, 4th Khoroo, Ulaanbaatar 15170, Mongolia;

E-Mail: saulegul_a@daad-alumni.de

4 Department of Urban Water and Waste Management, University of Duisburg-Essen, Universitätsstr. 15, Essen 45141, Germany; E-Mail: sonja.heldt@uni-due.de

* Author to whom correspondence should be addressed; E-Mail: j.hofmann@igb-berlin.de; Tel.: +49-30-6392-4073; Fax: +49-30-6392-4099.

Academic Editor: Say-Leong Ong

Received: 17 February 2015 / Accepted: 4 June 2015 / Published: 25 June 2015

\begin{abstract}
A comprehensive monitoring project (2006-2013) provided data on hydrology, hydromorphology, climatology, water physico-chemistry, sedimentology, macroinvertebrate community and fish diversity in the Kharaa River basin in northern Mongolia, thus enabling, for the first time, a detailed characterization of the stream landscapes. Surface waters were categorized into separate "water bodies" according to their identifiable abiotic and biocoenotic features, subsequently creating the smallest management sub-units within the river basin. Following the approach of the European Water Framework Directive (EC-WFD), in order to obtain a good ecological status (GES), four clearly identifiable water bodies in the Kharaa River main channel and seven water bodies consisting of the basin's tributaries were delineated. The type-specific undisturbed reference state of various aquatic ecosystems was identified in the assessment and used to set standards for
\end{abstract}


restoration goals. With regards to water quality and quantity, the upper reaches of the Kharaa River basin in the Khentii Mountains were classified as having a "good” ecological and chemical status. Compared with these natural reference conditions in the upper reaches, the initial risk assessment identified several "hot spot" regions with impacted water bodies in the middle and lower basin. Subsequently, the affected water bodies are at risk of not obtaining a level of good ecological and/or chemical status for surface waters. Finally, a matrix of cause-response relationships and stressor complexes has been developed and is presented here. The applicability of management approaches is discussed to better foster the development of a sustainable river basin management plan. The application of natural references states offers a sound scientific base to assess the impact of anthropogenic activities across the Kharaa River basin.

Keywords: water quality; water bodies; ecosystem service; river type; risk assessment; Kharaa River; Mongolia

\section{Introduction}

Stream landscape conditions in northern Mongolia range from close to pristine in their upper catchments, to rivers that are substantially affected by anthropogenic factors in their middle and lower reaches. These impacts have been attributed to the region's rapid economic development, which has been largely driven by the exploitation of mineral resources (e.g., gold), population growth, urbanization and the expansion of agricultural and grazing activities.

Human activities have modified the environment at both global and national scales, to the point where researchers have proposed the term "anthropocene" for the current geological epoch, to emphasize mankind's dominating influence on the geology and ecohydrology across the planet [1,2]. The existence of regions with limited human impact has become extremely rare, as the majority of aquatic ecosystems in the world has been disturbed or altered in some way and thus have subsequently lost their pristine characteristics [3-9]. Even in the sparsely populated, remote stream landscapes of Mongolia, it is likely that anthropogenic influences will considerably alter these nearly pristine regions in the near future.

Mongolia, a landlocked country in north-central Asia, is characterized by an extreme continental climate with strong seasonal contrasts [10]. Located in the transitional zone between the great Siberian taiga and the Central Asian desert, the climate is characterized by long, dry winters and short summers. Large daily and seasonal temperatures fluctuations are common, with relatively high numbers of cloudless days and low precipitation of approximately $230 \mathrm{~mm} \cdot \mathrm{yr}^{-1}$, falling predominantly (85\%) in the summer months. Mean monthly air temperatures in January range between minus $20{ }^{\circ} \mathrm{C}$ and minus $25{ }^{\circ} \mathrm{C}$, with minimum air temperatures dropping to minus $40{ }^{\circ} \mathrm{C}$. The maximum air temperature in summer can rise to $40{ }^{\circ} \mathrm{C}$ during the hottest parts of the day. A large percentage of the precipitation (between $85 \%$ and 95\%) evaporates and is therefore not available for infiltration or runoff generation, particularly during the summer [11,12]. 
Fluvial drainage systems in northern Mongolia belong mostly to the Arctic Ocean Basin (AOB), with the Selenge River Basin (SRB, total catchment area of $459,000 \mathrm{~km}^{2}$ ) being the major inflow to Lake Baikal (Figure 1) [13].

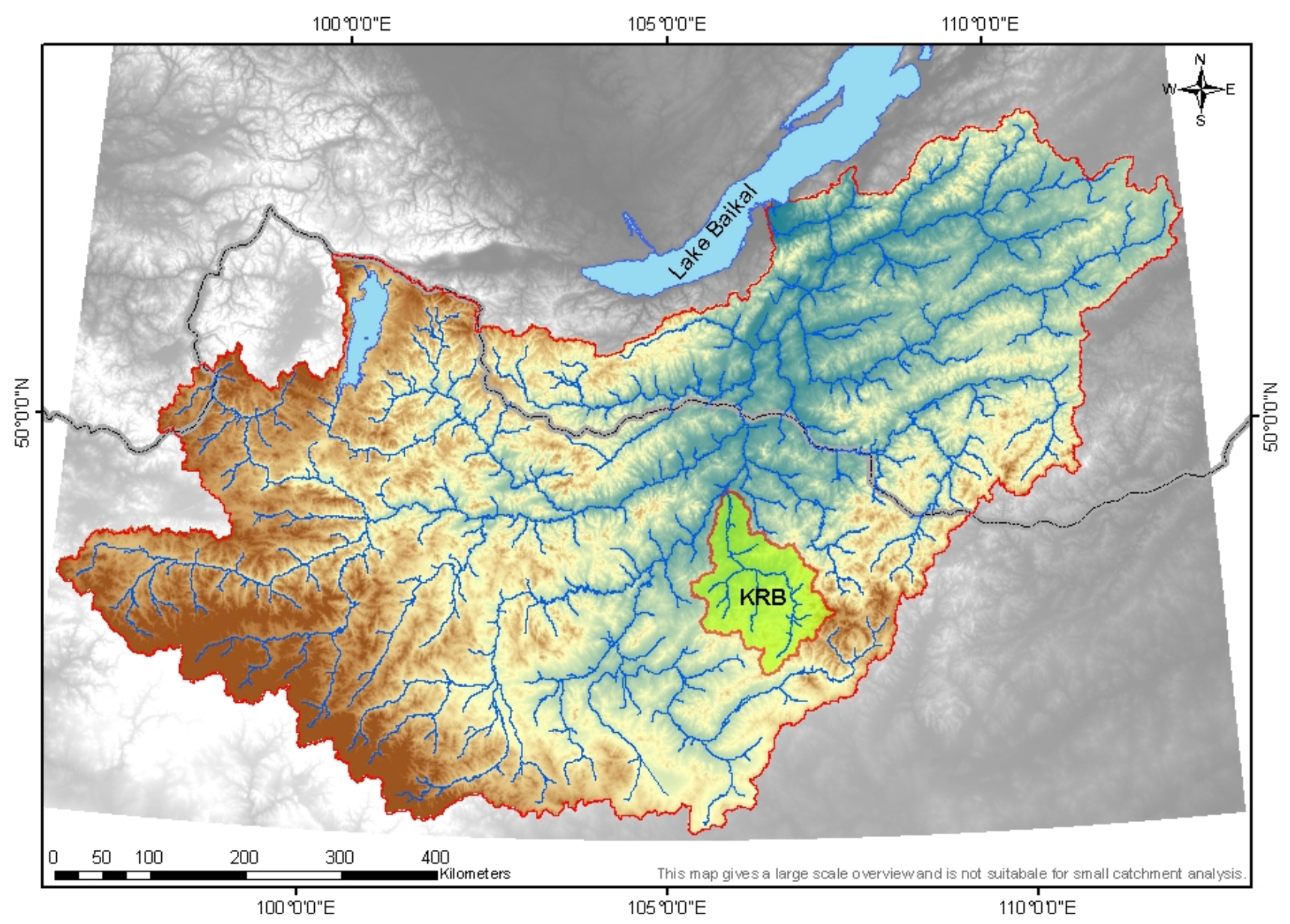

Figure 1. Orohydrographical map of the Selenge River Basin (SRB, catchment area 459,000 $\mathrm{km}^{2}$ ) in northern Mongolia with the location of the Kharaa River Basin (KRB, catchment area $14,534 \mathrm{~km}^{2}$ ).

The Kharaa River basin (KRB) is located within the SRB, positioned between latitudes 47.883 and $49.633^{\circ} \mathrm{N}$ and longitudes 105.316 and $107.366^{\circ} \mathrm{E}$. The basin covers an area of $14,534 \mathrm{~km}^{2}$ and is north of the capital Ulaanbaatar. An investigation of water quality and characterization of stream types was conducted in the KRB within the framework of a project focused on the development and implementation of a science-based Integrated Water Resource Management (IWRM) [14]. Various other research activities have also been carried out in and around the KRB in recent years [13-26].

The principal objectives of our current study on characterization and water quality assessment of stream landscapes were to:

(i) Characterize water bodies as basic units for water management planning;

(ii) Derive scientific based natural background conditions in the KRB for referencing purposes;

(iii) Identify ecological deficits in the Kharaa River as a consequence of diffuse and point source emissions (e.g., excess nutrients and heavy metals) and degradation of vegetation (which triggers erosion and causes increased riverine sediment loads); 
(iv) Conduct an initial risk assessment to identify where there has been a failure to meet environmental criteria relating to a good chemical and ecological status for running surface waters in the KRB; and finally,

(v) Identify, localize and prioritize protection and rehabilitation measures.

The overall objective is to promote the discussion on water quality assessment and to establish the concepts of protection and rehabilitation measures for the future implementation of a river basin management plan (RBMP) that is based on objective scientific data.

\subsection{The Physiogeographic Setting of the Kharaa River Basin}

The Kharaa River originates in the Khentii Mountains in northern Mongolia and flows north-northwest joining the Orkhon River within the greater SRB. Based on digitized topographical maps, the length of the main river channel was determined, starting with km "zero" at the confluence between the Kharaa and Orkhon rivers $\left(49.6316^{\circ} \mathrm{N}, 105.8335^{\circ} \mathrm{E}, 657 \mathrm{~m}\right.$ a.s.l.) and ending at river $\mathrm{km} \mathrm{313}$, at the confluence with the Mandalin Gol and Sugnugr Gol, the main source tributaries of the Kharaa River in the upper reaches $\left(48.4343^{\circ} \mathrm{N}, 106.76621^{\circ} \mathrm{E}, 1091 \mathrm{~m}\right.$ a.s.l.). The river name "Kharaa” is used only downstream of the river confluence from Mandalin and Sugnugr Gol [15].

From the headwaters in the southeast, to the outlet in the northwest, the Kharaa River cuts across several major morphological and geological units and fault zones of the Mongol-Baikal Lake tectonic system, including the main Mongolian lineament [16]. Most of the river basin is covered by grassland (59\%) and forest (26\%) with the portion of arable land only 11\% [19] (Figure 2).

Based on distinctive geomorphology, geotectonics and climatology the KRB can be distinguished into three sections:

1. The upper reaches comprising the sub-basins 1 to 5 in Figure 2, are characterized by mid- to high mountain ranges of the Khentii Mountains and generate the highest specific runoff rates (average $2.45 \mathrm{~L} \cdot \mathrm{s}^{-1} \cdot \mathrm{km}^{-2}$ ) of the entire river basin thus being the main water source ("water tower" [5]) for the lower catchment.

2. The middle reaches (sub-basins 6 to 8 in Figure 2) have lower specific runoff rates (average $0.7 \mathrm{~L} \cdot \mathrm{s}^{-1} \cdot \mathrm{km}^{-2}$ ), the relief is dominated by broad valleys with significant terrace levels and hilly uplands with gentle slopes; the drainage pattern is confined to some active highly-sinuous channels which are interconnected with numerous abandoned channels in a fluvial floodplain.

3. The lower reaches (sub-basins 9 and 10 in Figure 2), also have low specific runoff and are typical open steppe and lowland landscapes with features of peneplain formation processes, where the vegetation of the fluvial floodplain has been degraded by overgrazing.

The long-term (1990-2012) average monitored discharge of the Kharaa River is approximately $11.5 \mathrm{~m}^{3} \cdot \mathrm{s}^{-1}$ at the outlet of the basin (gauge station Buren Tolgoi, $49.5914^{\circ} \mathrm{N}, 105.8591^{\circ} \mathrm{E}$ ). This is equivalent to a mean specific runoff of $0.83 \mathrm{~L} \cdot \mathrm{s}^{-1} \cdot \mathrm{km}^{-2}$ [18].

The entire population of the Kharaa River basin is 147,000 (census data as of 2005, mean population density about 10 inhabitants $\mathrm{km}^{-2}$ ), with most of the inhabitants living in the city of Darkhan (75,000 inhabitants), located near the river basin outlet [15]. 


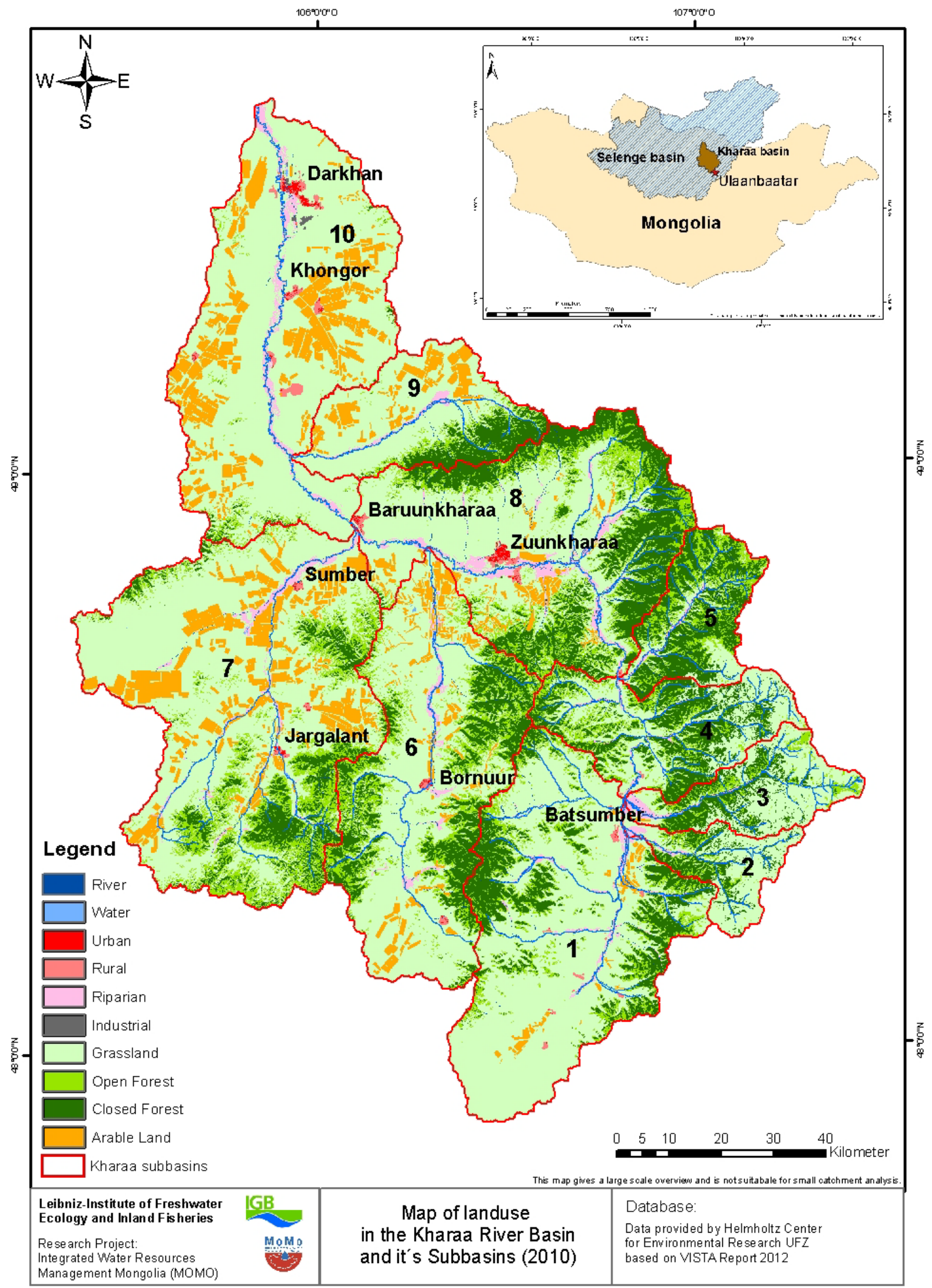

Figure 2. Land-use in the Kharaa River basin in 2010. The numbers in black indicate the individual sub-basins that have been chosen for nutrient emission and hydrological modeling purposes $[15,17]$. Note that the class of arable land also contains portions of fallow land. As shown in the overview map (upper right corner), the Kharaa River basin (dark area) is part of the Selenge catchment (hatched area), which drains into Lake Baikal. 
Agricultural production on arable land is conducted using a rotation system, with wheat being the dominant crop, and to a lesser extent potatoes, which are commonly used as cash crops in the KRB [20]. Livestock grazing has been the principal land-use type in the catchment over the last decades. However, since the collapse of the former socialist system in 1990/1991, the de-regulation of pastoralism has led to increased herd sizes and a concentration of grazing near cities and on the river floodplains. Despite severe livestock losses due to a series of dry summers followed by winters with heavy snowfall (Mongolian; Dzud) in the period 1997 to 2003 and 2009/2010, the national stocking rate of grazing animals has increased dramatically from 25 million (1990) to recent record levels close to 50 million animals. The livestock numbers in the KRB are estimated to be currently around 1.5 million animals [20].

Another important driver of land-use changes is the mining sector. Due to the geological situation in the main Mongolian lineament, gold-mining has been well developed in the middle reaches with the focus of production occurring in the Boroo and Gatsuurt gold mining areas. Currently, more than 20 mines operate within the KRB $[18,21]$.

\subsection{Monitoring of Surface Water Quality in the KRB}

As a part of Mongolia's freshwater quality monitoring network, the hydrochemical assessment of the surface water in the KRB has been conducted since 1986 by the Central Laboratory for Environment and Meteorology, IMHE [13]. The results from a monitoring study at five sampling sites (one site both upstream and downstream of Zuunkharaa, one site both upstream and downstream of Darkhan, and one site at Baruunkharaa, see Figures 2 and 3 and Table 1), for the period from 1986 to 2011 have been evaluated [13].

In addition to the state agency monitoring program, a long-term water quality monitoring program has been conducted under the research aims of the project entitled "Integrated Water Resources Management (IWRM) in Central Asia: Model Region Mongolia” (MoMo Phase I and II, http://www.iwrm-momo.de [27]) during the period 2007 to 2013. As a result of the water quality monitoring programme, a database was established for hydrochemistry (general physical-chemical parameters, major ions, nutrient and heavy metals), hydrology (long-term run-off data) and hydrobiology (community compositions of diatoms, macroinvertebrates and fish populations) in the KRB. The spatial allocation of sampling sites, wastewater treatment plants (WWTP), the mapped gold mines and other areas with contamination potential are shown in Figure 3.

The results of the long-term assessment of the water quality monitoring and ecological status in the KRB have been published in numerous reports and scientific papers [15,17,27-39]. Heavy metal pollution [21,40,41], eutrophication [15], a loss of habitats and biodiversity [15] and fine-grained sediment impacts $[31,32,42]$ have been found to occur in the KRB.

Researchers at the Institute of Geography/Geoecology (Mongolian Academy of Sciences) have conducted surface water quality monitoring in the Orkhon River basin, including the Kharaa River, from 2009 to 2014. The physical-chemical measurements, major ions and nutrients were measured twice a year in surface waters during the ice free period, while heavy metal concentrations were determined in surface waters and sediments. Aluminium, mercury and arsenic levels were found to be greatly elevated in the streambed sediment of one of the Kharaa River's mid-catchment tributaries, the Boroo River, as well as in the main channel [22,43]. Within the middle reaches of the Boroo River, 
mercury concentrations were highly significant due to a 1956 explosion of a storage tank containing liquid mercury. Large quantities of this toxic heavy metal, which was and currently still is used during the amalgamation of gold in the small scale mining operations, were released into the surrounding environment contaminating the resident fauna. There were also considerable amounts of mercury known to have been released in the lower catchment during the Khongor incident in 2007 [40]. As a result of this heavy metal pollution in the basin there is a concern of uptake into the food chain and thus affecting human health by fish consumption also further downstream in the Russian part of the SRB [44].

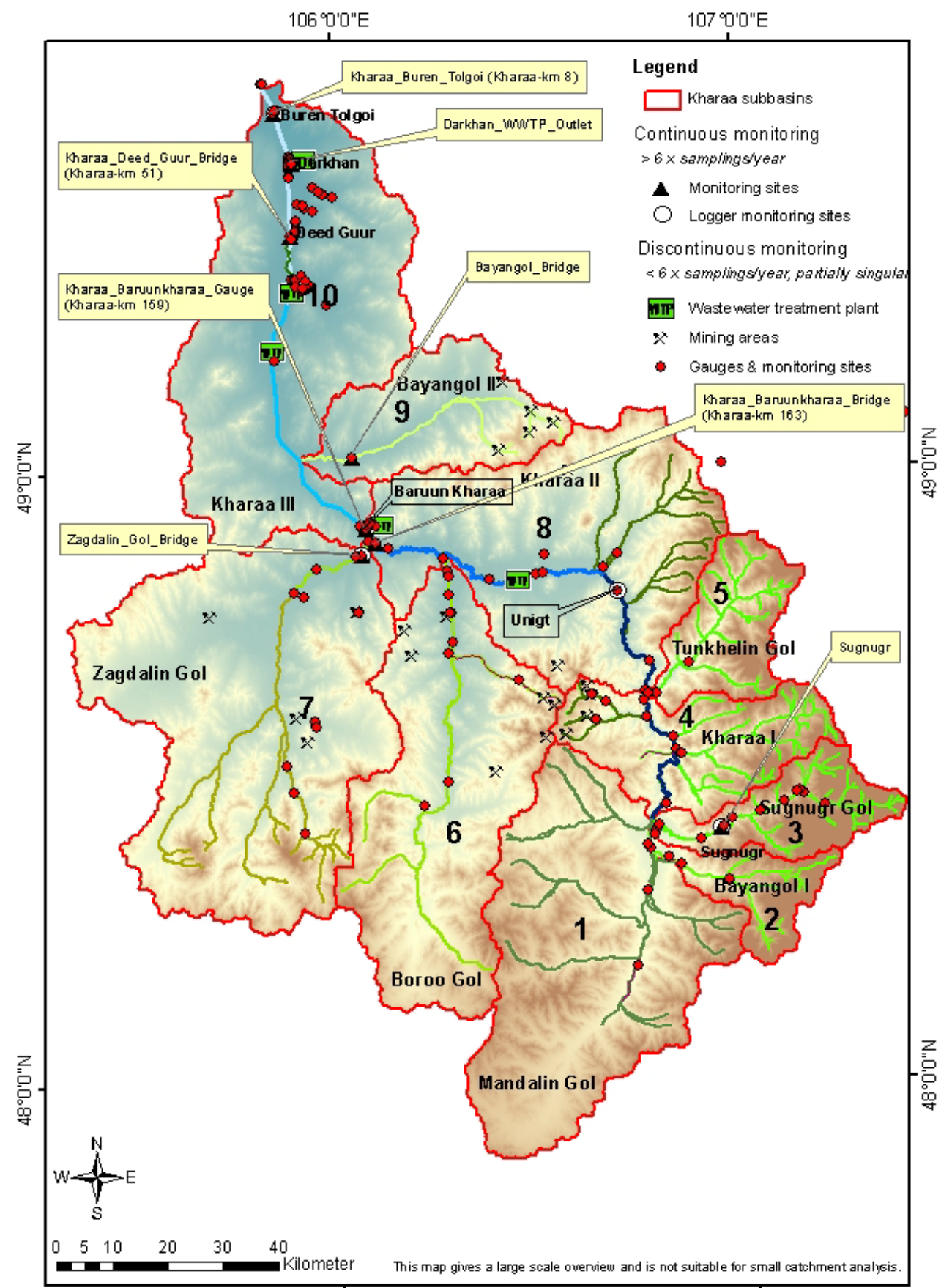

Figure 3. Continuous and discontinuous water quality monitoring in the KRB. In addition, the location of mining areas, contaminated areas and wastewater treatment plants (WWTP) is indicated. The numbers in black refer to the hydrological sub-basins in the text. The color of river network is explained in Figure 4. 
Table 1. Sampling points for hydromorphology, discharge, physico-chemistry, macroinvertebrates, diatoms and fish. The unequivocal primary code ID (second column from left) allows the allocation of systematic site names for all locations (e.g., Sel_Kh10_001; Sel = Selenge River basin district. Kh $=$ Kharaa river basin, $10=$ Sub-basin 10 of KRB [15], $001=$ numbers of water bodies and water usages (001-200 = Surface water bodies of running waters, e.g., rivers).

\begin{tabular}{|c|c|c|c|c|}
\hline $\begin{array}{c}\text { Sampling Point (MoMo) } \\
\text { Monitoring Site (IMHE) } \\
\text { Kharaa Mileage (km) } \\
\end{array}$ & $\begin{array}{c}\text { Primary Code } \\
\text { ID }\end{array}$ & Latitude $\left({ }^{\circ} \mathrm{N}\right)$ & Longitude $\left({ }^{\circ} \mathrm{E}\right)$ & $\begin{array}{r}\text { Elevation } \\
\text { (m a.s.l.) }\end{array}$ \\
\hline $\begin{array}{l}\text { Kh_1. Buren_Tolgoi_Gauge/WQM Logger. } \\
\text { Kharaa Darkhan downstream (Kharaa km 8) }\end{array}$ & Sel_Kh10_001 & 49.5914167 & 105.859116 & 664 \\
\hline $\begin{array}{c}\text { Kharaa_Deed_Guur_Bridge. Kharaa } \\
\text { Darkhan upstream (Kharaa km 51) }\end{array}$ & Sel_Kh10_008 & 49.3899 & 105.897183 & 703 \\
\hline Kh_2. Kharaa River. downstream of Darkhan & Sel_Kh10_003 & 49.52111 & 105.89469 & 673 \\
\hline Kh_3. Kharaa_Khongor & Sel_Kh10_009 & 49.31932 & 105.9003 & 708 \\
\hline Kh_3.5. Kharaa_ds_Baruunkharaa & Sel_Kh08_012 & 48.93874 & 106.01187 & 783 \\
\hline $\begin{array}{c}\text { Kh_4. Kharaa River. } \\
\text { downstream of Baruunkharaa }\end{array}$ & Sel_Kh10_011 & 48.91589 & 106.06043 & 787 \\
\hline $\begin{array}{l}\text { Kharaa_Baruunkharaa_Gauge_WQM_Logge } \\
\text { r. Kharaa-Baruunkharaa. (Kharaa km 159) }\end{array}$ & Sel_Kh10_012 & 48.91165 & 106.075033 & 796 \\
\hline $\begin{array}{c}\text { Kh_5. Kharaa River. } \\
\text { upstream of Baruunkharaa }\end{array}$ & Sel_Kh08_002 & 48.87986 & 106.1299 & 804 \\
\hline $\begin{array}{l}\text { Kh_6. Kharaa-Zuunkharaa } \\
\text { downstream(Kharaa km 203) }\end{array}$ & Sel_Kh08_003 & 48.82686 & 106.37845 & 840 \\
\hline $\begin{array}{l}\text { Kharaa_Zuunkharaa_bridge. Kharaa- } \\
\text { Zuunkharaa upstream (Kharaa km 219) }\end{array}$ & Sel_Kh08_004 & 48.8332 & 106.49383 & 859 \\
\hline $\begin{array}{l}\text { Kh_7. Kharaa River. } \\
\text { upstream of Zuunkharaa bridge }\end{array}$ & Sel_Kh08_005 & 48.8346 & 106.50909 & 865 \\
\hline Kh_8. Kharaa_Unigt_discharge_Logger & Sel_Kh08_006 & 48.80335 & 106.6922 & 915 \\
\hline Kh_8.3 & Sel_Kh08_011 & 48.67167 & 106.77667 & 944 \\
\hline Zagdalin_Gol_Bridge_WQM_Logger & Sel_Kh07_002 & 48.86691 & 106,06457 & 796 \\
\hline $\begin{array}{l}\text { Kh_8.5. Kharaa River. } \\
\text { Railway Station km } 290\end{array}$ & Sel_Kh04_002 & 48.54406 & 106.82719 & 1048 \\
\hline Sug_2 & Sel_Kh03_005 & 48.45431 & 107.09087 & 1304 \\
\hline Sugnugur_WQM_Logger & Sel_Kh03_009 & 48.41322 & 106.93521 & 1180 \\
\hline Sug_1 & Sel_Kh03_010 & 48.39673 & 106.8839 & 1159 \\
\hline Mand_2 & Sel_Kh01_002 & 48.31394 & 106.75099 & 1127 \\
\hline Mand_1 & Sel_Kh01_001 & 48.18985 & 106.72505 & 1179 \\
\hline Tun_1 & Sel_Kh05_002 & 48.63501 & 106.78388 & 1005 \\
\hline Shiv_1 & Sel_Kh08_008 & 48.86604 & 106.69608 & 938 \\
\hline Bor_0.5 & Sel_Kh06_002 & 48.84052 & 106.27373 & 830 \\
\hline Zag_1 & Sel_Kh07_001 & 48.89111 & 106.08071 & 801 \\
\hline Gatsuurt_brook_ds_Goldmine & Sel_Kh04_008 & 48,62381 & 106,66052 & 1126 \\
\hline Baya_1 & Sel_Kh02_004 & 48.3672 & 106.80424 & 1121 \\
\hline
\end{tabular}




\subsection{Water Management in Mongolia}

The beginning of the new millennium saw an increased awareness in Mongolia regarding the vulnerability of the country's water resources in terms of quality and quantity and the role water will play as a basis for the country's socio-economic development [33]. As a result, a policy focusing on the sustainable use of water resources has gradually been developed. Mongolia's Water Law (2012) [45] declared Integrated Water Resource Management (IWRM) to be implemented at the river basin scale, as the core concept for national water management $[36,46]$.

Mongolia has continually reformed its water policies with the objective to solve the main challenges of institutionalizing river basin management (RBM) and IWRM. However, the continued ongoing transformations in other political, social and economic sectors sometimes constitutes additional challenges for the implementation of these reforms at both a national and river basin level $[33,36]$. Mongolia's water sector is very complex, involving six national ministries, 13 main agencies and several minor agencies [47]. In total, eight national laws deal with the protection, use and restoration of water resources. Moreover, there is overlapping legislation with regards to the protection and sustainable use of air, land, forest, wildlife and mineral resources [48]. The Water Law of 2012 [45] was intended as an "umbrella", coordinating all laws and by-laws concerning the water sector. One of its main requirements is the development of a national IWRM plan for Mongolia and each of the country's 29 river basins [49].

The resulting River Basin Management Plans (RBMPs) are expected to fulfil four main tasks: (1) to assess the status of each specific river catchment; (2) to prevent potential water scarcity; (3) to protect water resources against pollution and (4) to allocate and use water resources in the most efficient way. The recommended measures should be implemented from 2015 to 2021 [47].

\section{Materials and Methods}

The Mongolian water sector is in a period of dynamic institutional transition [49], thus addressing problems of data scarcity requires a flexible and adaptable approach, such as proposed by the Integrated Water Resource Management (IWRM) concept. In addition, it is argued that the methodology of the EC Water Framework Directive (EC-WFD, EC 2000/60/EC) [50], can only partly serve as a model for IWRM implementation at a river basin-scale in Mongolia [33]. The fundamental difference in the assessment of European waterways, is the consistency in the definition of the reference conditions for the classification of surface waters, as well as the need to develop monitoring tools to integrate the structure and functioning on the ecosystem level. Following this approach, our objectives are set relative to the ecological quality rather than physico-chemical thresholds, as in existing Mongolian legislation. Thus, our reference screening criteria did not only incorporate physico-chemical, hydro-morphological (Section 2.4) and pressure criteria to identify reference sites, but also the spatial and temporal variability within the biological communities (Section 2.3). The Europe wide applicability of the EC-WFD methodology covers also the Pannonian ecoregion (including all of Hungary) with the westernmost areas of the Eurasian forest steppes, which form part of a band from Eastern Europe almost to the Pacific coast. This vast system consisting of alternating forest and grassland patches forms a mosaic-like landscape, such as the Daurian forest-steppe in northern Mongolia (Section 3.1). 
One important provision of the EC-WFD, is that all assessments of surface waters must be based on sound surface water typologies. Consequently, we used the descriptors of the "Working Group of the Federal States on water issues" (Bund/Länder-Arbeitsgemeinschaft Wasser, LAWA) [51,52] subcommittee "Biological Stream Assessment and Inter-calibration in Accordance with the EC-WFD" to differentiate between water body types based on their specific abiotic and biotic characteristics.

We defined the following procedure for the assessment of the chemical and ecological status of the Kharaa River basin:

(a) Delineation of stream types in accordance with Pottgiesser and Sommerhäuser [52];

(b) Classification of water bodies (according to EC-WFD, Article 2, point 10 and EC-WFD) [50];

(c) Characterization of natural reference conditions to gain information on natural background levels;

(d) Initial assessment (surface water quality and ecology) of distinct water bodies;

(e) Determination of protection/development measures.

\subsection{Methodology and Descriptors of Stream Types}

Obligatory and optional descriptors used by LAWA [51,52] to delineate stream types include ecoregion, altitude, geology and geomorphology according to the river landscapes and regions [53], stream slope and size.

As there has been no stream type classification system established in Mongolia prior to this research it was decided to apply an approach which was originally designed for German rivers [52]. Although applying this approach to Mongolian rivers does certainly have limitations, the overall character (hydro-dynamics, morphology, and general fauna elements) of the streams and rivers in the KRB are similar to running waters in mountainous and steppe regions of central Europe. Therefore, this approach including certain specific adaptations, especially with regards to the fauna assessment, is assumed to be sufficient for a first basal description of the Kharaa River catchment water bodies. The profiles of the identified river types in the Kharaa River catchment (Supplementary Material S.1.) include a general hydro-morphologic characterization. The numerical information gives representative ranges typical for a certain stream type.

As a consequence of missing reference sites for some river types, reference taxa lists were not included but a more general ecological characterization of the aquatic communities are provided as a result of expert knowledge and analysis. There is need for further research including different geographic and climatic regions to provide a more detailed and reliable fauna dataset, which can only be achieved with commissioned research projects in cooperation with Mongolian state agencies. Furthermore, it should be noted that only the water bodies of the KRB have been included into the classification given in the Supplementary file (Supplementary Material S.1.), and therefore, it cannot be applied without adaptations to other regions in Mongolia where it is most likely that additional river types first need to be included to achieve a robust classification of Mongolia's running waters in the future.

\subsection{Delineation of Surface Water Bodies in the KRB}

The definition of a water body is given by the European Community Common Implementation Strategy (EU CIS) Guidance Document No. 2 [54], as being the smallest management sub-unit within 
a river basin that unambiguously represents a river section of coherent hydrology and geology of the overall status and thus identifies the most appropriate management unit. This methodology provides the base to allocate each water body to a dominant stream type, its ecoregion and its characteristic biocoenosis. We defined a unique primary code key to identify all monitoring sites (including the levels of project driven, state driven and other research driven monitoring sites in the KRB) and to allocate them to distinct water bodies (Table 1).

The description of the water bodies in the KRB was conducted based on geographic position, altitude, size and geology according to "System A" of the EC-WFD [50], which is a well-established method in Europe and was assumed to be applicable due to the similarity of streams and rivers of the KRB and those known from mountainous regions in central Europe. In a subsequent step, this abiotic differentiation was compared with divisions based on existing biological data and expert judgement.

For a proper description of the surface water bodies, they must not overlap with each other. If there are significant differences in the status of the different parts of a river, it must be sub-divided into separate water bodies to achieve the desired environmental objective in the most cost effective way $[55,56]$.

\subsection{Biological Data}

To ensure a comprehensive and robust biological assessment, data on macroinvertebrate and fish populations were collected from 21 sampling sites (Table 1) and were compiled by the IWRM research project "MoMo" [27]. In addition, the state surveillance monitoring data from the Mongolian Academy of Sciences (MAS) concerning the diatom assemblages were also included.

Macroinvertebrates and fish were sampled during field surveys conducted between 2006 and 2012, to gather information regarding species compositions and to then identify possible environmental impacts using bio-assessment methods. A standardized sampling procedure (multi-habitat sampling) was used to analyze aquatic macroinvertebrates at each sampling site [57]. The major habitats on the river substrate were sampled in proportion to their occurrence within a chosen sample reach (approx. 5-10 times the river width). A detailed description of the sampling procedure was given by Hofmann et al. [15] and Avlyush et al. [28]. After sample analysis, a meaningful set of robust structural and functional macroinvertebrate community metrics was applied in order to assess the ecological status at each corresponding sampling station [15] (Table 2).

The macroinvertebrate fauna of the KRB was composed of 211 different subgenera and genera or higher taxonomic groups belonging to 24 orders [15]. Altogether 131 species belonging to EPT (63 Ephemeroptera, 18 Plecoptera, 50 Trichoptera) have been identified. For estimation of reference conditions, the community compositions of sites with the lowest anthropogenic impact from the first two sampling campaigns were assumed to be sufficient. From the metric sets used, a preliminary evaluation of the ecological status at the sampling sites was made [15].

During surveys with higher temporal resolution, the seasonal variability in the assessment results could be detected at different sites. This was largely identified as life cycle determined changes in the aquatic macroinvertebrate community due to a large proportion of insect species with aerial stages. Best assessments have resulted from analyzing macroinvertebrate communities during the summer 
months from June to August and therefore this period is recommended for macroinvertebrate biomonitoring activities in Mongolia in the future.

Table 2. Threshold values of metrics used for ecological quality assessments by benthic invertebrate assemblages in the KRB. For explanation of water bodies and river types see Tables 4 and 5.

\begin{tabular}{|c|c|c|c|c|c|}
\hline \multirow[t]{2}{*}{ Metric Set } & \multicolumn{5}{|c|}{ Ecological Quality } \\
\hline & Excellent & Good & Moderate & Poor & Bad \\
\hline \multicolumn{6}{|c|}{ Water Bodies of Kh_Main_1, Kh_Main_2, Kh_Trib_2 } \\
\hline Taxa richness & 40 & 30 & 25 & 20 & $<20$ \\
\hline Plecoptera taxa & 4 & 3 & 2 & 1 & 0 \\
\hline Ephemeroptera taxa & 15 & 13 & 10 & 5 & $<5$ \\
\hline Percentage of EPT individuals (\%) & 50 & 40 & 30 & 20 & $<20$ \\
\hline Shannon diversity & 2.2 & 2 & 1.5 & 1.2 & $<1.2$ \\
\hline Percentage of fine substrates colonizer’s density (\%) & 15 & 30 & 50 & 70 & $>70$ \\
\hline \multicolumn{6}{|c|}{ Water Bodies Kh_Trib_1, Kh_Trib_3, Kh_Trib_4, Kh_Trib_6 } \\
\hline Taxa richness & 30 & 25 & 20 & 15 & $<15$ \\
\hline Plecoptera taxa & 4 & 3 & 2 & 1 & 0 \\
\hline Ephemeroptera taxa & 12 & 10 & 8 & 5 & $<5$ \\
\hline Percentage of EPT individuals (\%) & 50 & 40 & 30 & 20 & $<20$ \\
\hline Shannon diversity & 2.2 & 2 & 1.5 & 1.2 & $<1.2$ \\
\hline Percentage of fine substrates colonizer’s density (\%) & 30 & 40 & 60 & 80 & $>80$ \\
\hline \multicolumn{6}{|c|}{ Water Bodies Kh_Main_3, Kh_Main_4 } \\
\hline Taxa richness & 40 & 30 & 20 & 15 & $<15$ \\
\hline Ephemeroptera taxa & 15 & 13 & 10 & 5 & $<5$ \\
\hline Percentage of EPT individuals (\%) & 50 & 40 & 30 & 20 & $<20$ \\
\hline Shannon diversity & 2.2 & 2 & 1.5 & 1.2 & $<1.2$ \\
\hline Percentage of fine substrates colonizer’s density (\%) & 30 & 40 & 60 & 80 & $>80$ \\
\hline
\end{tabular}

The bio-assessment of fish communities was completed using standardized electrofishing methods. In order to allow comparability between sampling sites, a catch per unit effort (CPUE) approach was used. During the investigations in the Kharaa River catchment, 14 fish species belonging to nine families were recorded [15]. These represent $64 \%$ of the total species inventory of the Selenge watershed [58]. The number of individuals caught at a specific sampling site were counted. Species were identified on site and total length was measured. For the ecological quality assessment, the fish-based assessment system (FIBS) [59] was used. As no reference data for fish communities was available for the assessment, Mongolian and German ichthyologists developed a reference list for the different ecoregions considering the relative abundances of each fish species (Table 3).

With respect to the diatom assemblages a total of 338 species belonging to 58 genera, comprised nearly 65\% of the 516 taxa listed in Mongolia [60]. The research results on diatom assemblages in the $\mathrm{KRB}$ and its possible application as a bio-assessment tool are yet to be published. 
Table 3. Fish species composition used as reference for the ecological assessment of rivers in the KRB.

\begin{tabular}{|c|c|c|c|c|}
\hline \multirow[b]{2}{*}{ Fish Species } & \multicolumn{4}{|c|}{ Relative Abundances (\%) per River Type } \\
\hline & $\begin{array}{c}\text { Mid-Sized and } \\
\text { Large Lowland } \\
\text { Rivers Dominated } \\
\text { by Sand and Loam }\end{array}$ & $\begin{array}{c}\text { Large Gravel Rich } \\
\text { Highland Rivers }\end{array}$ & $\begin{array}{c}\text { Small Siliceous } \\
\text { Highland Rivers } \\
\text { Dominated by } \\
\text { Coarse Substrate }\end{array}$ & $\begin{array}{c}\text { Small Siliceous } \\
\text { Highland Rivers } \\
\text { Dominated by Fine } \\
\text { Substrate }\end{array}$ \\
\hline Leuciscus idus (Linnaeus. 1758) & 2.5 & - & - & - \\
\hline Silurus asotus (Linnaeus. 1758) & 0.5 & - & - & - \\
\hline Thymallus baicalensis (Dybowski. 1874) & 0.5 & 6.0 & 15.0 & 0.5 \\
\hline Perca fluviatilis (Linnaeus. 1758) & 1.5 & - & & - \\
\hline Phoxinus phoxinus (Linnaeus. 1758) & 0.5 & 62.0 & 55.0 & 60.0 \\
\hline Carassius gibelio (Bloch. 1782) & 15.0 & - & - & - \\
\hline Esox lucius (Linnaeus. 1758) & 0.5 & 0.5 & - & - \\
\hline Cyprinus carpio (Linnaeus. 1758) & 2.5 & - & - & - \\
\hline Brachymystax lenok (Pallas. 1773) & 0.5 & 2.5 & 8.0 & 0.5 \\
\hline Lota lota (Linnaeus. 1758) & 2.5 & 0.5 & 0.5 & 0.5 \\
\hline Barbatula spp. & - & 10.0 & 20.5 & 8.0 \\
\hline Leuciscus baicalensis (Dybowski. 1874) & 56.5 & 10.0 & - & 20.0 \\
\hline Acipenser baerii baicalensis (Nikolskii. 1896) & 0.5 & - & - & - \\
\hline Rutilus rutilus lacustris (Pallas. 1814) & 1.0 & - & - & - \\
\hline Cobitis melanoleuca (Nichols. 1925) & 15.0 & 6.0 & 0.5 & 10.0 \\
\hline Hucho taimen (Pallas. 1773) & 0.5 & 2.5 & 0.5 & 0.5 \\
\hline Sum & 100 & 100 & 100 & 100 \\
\hline
\end{tabular}

\subsection{Abiotic Data (Physico-Chemistry, Hydrology, Hydromorphology)}

The physico-chemical data is based on long-term surveillance monitoring by Mongolian authorities (IMHE, data available since 1986 for two stations upstream and downstream of Darkhan, Table 1), as well as the projects surveillance monitoring with detailed longitudinal stream surveys in spring, summer and autumn from 2006 to 2013. Total nitrogen, ammonium, nitrate, nitrite, ortho-phosphate and total phosphorus were selected as water quality parameters for nutrients. As pollution indicators 11 heavy metal and metalloid elements ( $\mathrm{Al}, \mathrm{As}, \mathrm{Cd}, \mathrm{Cr}, \mathrm{Cu}, \mathrm{Fe}, \mathrm{Mn}, \mathrm{Hg}, \mathrm{Ni}$, $\mathrm{Pb}, \mathrm{Zn}$ ), as well as chloride and boron were selected. All parameters were analyzed in German laboratories (Berlin and Magdeburg) according to the national standards for quality assurance of water analyses.

Furthermore, three water quality measurement stations were installed at different locations in the catchment in the summer of 2011 to continuously monitor the dynamics of water quality parameters. These stations were located at: (a) Station Buren Tolgoi close to the catchment outlet approximately $15 \mathrm{~km}$ north of the city of Darkhan (Table 1, sub-basin 10 in Figure 3); (b) Station Baruunkharaa in the middle reaches of the catchment, adjacent to the intense agricultural and mining areas (Table 1, sub-basin 8 in Figure 3); (c) Station Sugnugr in one of the pristine headwaters in the Khentii Mountains (Table 1, sub-basin 3 in Figure 3). All three stations were equipped with optical YSI 6820 V2 probes (YSI Inc., Yellow Springs, OH, USA) that measured dissolved oxygen, $\mathrm{pH}$, temperature and electrical 
conductivity at 15 min time steps during the ice free months from June to September 2012. All of the data was imported into a database and following an outlier separation, statistical analysis was undertaken to compare each station (Supplementary Material S.2.).

The hydro-morphological situation along the Kharaa River was mapped during field surveys in 2006-2007 [30] and during 2009-2011. Six main parameters and 31 sub-parameters were recorded at river sections of 100, 500 or 1000 m lengths and evaluated on a seven step scale. The main parameters included (i) development of the river course; (ii) longitudinal profile; (iii) morphology of the river bed; (iv) cross-sectional profile; (v) morphology of the river banks and (vi) surroundings (until $100 \mathrm{~m}$ on both sides of the bank). The details of the assessment protocol are given in Landesamt für Natur, Umwelt und Verbraucherschutz, Nordrhein-Westfalen, Germany, LaNUV [61].

The hydromorphological findings provide proof for minimal human induced changes and alterations of the natural dynamics of discharge and river bed morphology. Cut-off meanders and dams exist only near Darkhan at the bridge of Deed Guur (Supplementary Material S.1., LAWA river type 15, picture 4). Near Zuunkharaa and Buren Tolgoi, water is abstracted via irrigation channels. In general, the Kharaa River is a free flowing, meandering hydrological system without any weirs and reservoirs. However, the reference conditions for the natural dynamics of river floodplains are existent only in parts of the upper, middle (near sampling site Kh_8, Table 1) and lower most reaches (at the confluence of the Orkhon and Kharaa rivers, Supplementary Material S.1., LAWA river type 15, pictures 2 and 3), due to extensive livestock grazing. Thus the decline of riparian vegetation and its biodiversity is a significant ecological threat in many parts of the river course.

\subsection{Initial Risk Assessment of Surface Water Bodies in the KRB}

The preliminary risk assessment indicated the KRB failed to obtain a good environmental rating for both chemical and ecological standings for running surface waters. The assessment was performed as follows:

(a) For each individual surface water body a rating matrix (Supplementary Material S.3., Tables S1 to S11) was developed;

(b) Definitions of indicators and their ranges are included;

(c) The assessment is based on the natural reference status. For physico-chemical indicators the natural reference conditions are given by the values of the surface water body group Kh_Trib_2 (Khentii reference). For the biological assessment the reference conditions of the quality components “macroinvertebrates” and “fish fauna” have been used. Hydromorphological reference conditions were monitored separately;

(d) Erosion was integrated as part of the suspended load and was considered as turbidity within the physicochemical characteristics;

(e) Heavy metals were investigated with a focus on priority substance concentrations;

(f) For the map visualization the "Initial risk assessment of surface waters in the KRB" was chosen to reflect a traffic light color system: red $=$ at risk, yellow $=$ possibly at risk, green $=$ not at risk, grey = no data (Supplementary Material S.3.); 
(g) Additionally, the allocation of these colors followed the principle of the worst case scenario. Thus the worst result of an individual indicator dictates the final overall rating. For example, if only one quality component of an individual water body lies within the red range, the entire water body is marked in red color. The detailed data background is shown in Tables 7 to 10 and in Supplementary file, Supplementary Material S.3.;

(h) The main aim of the risk assessment map is to allow for the visualization of the situation at a glance. Detailed information is provided in the Supplementary files, Supplementary Material S.3. (Tables S1 to S11);

(i) For reasons of scale, the map allows only an overview and not an exact allocation.

Finally, the results were summarized and visualized in the preliminary map of the risk assessment (Section 3.5). To show at a glance, if the environmental objective of a good chemical and/or ecological status of running waters was achieved, three different categories were distinguished:

- Surface water body at risk (red): running waters with a sufficient data base for the ecological and chemical status, and substantial evidence of existing deteriorations which make a good chemical and ecological status unlikely to be attained.

- Surface water body possibly at risk (yellow): running waters with evidence of deteriorations in single cases, whose delineations is aggravated due to incomplete and lacking data base and where the attainment of a good chemical and ecological status is unclear.

- Surface water body not at risk (green): running waters in the source area of the Khentii Mts. with very low population density, low land-use intensity, drinking water usage of running waters with good to very good water quality (e.g., Sugnugr Gol in the Khentii Mts.). The attainment of a good chemical and ecological status has been identified.

\section{Results and Discussion}

\subsection{Profiles of Stream Types in the KRB}

The KRB falls into two ecoregions, the Transbaikal coniferous forest and the Daurian forest steppe with grasslands and shrublands. The open steppe vegetation is a combination of pine (Pinus silvestris) and aspen (Populus tremula) amidst steppe flora.

By adapting the approach of Pottgiesser et al. [51] the rivers in the KRB could be assigned to five different biocoenotically relevant stream types, see Table 4, Supplementary file, Supplementary Material S.1.

Altogether five stream types out of the 25 German ones could be identified in our study. Large rivers (stream types 10 and 20) were not included as a different assessment scheme has to be used for these types [62]. 
Table 4. Description of specific river types in KRB, their eco- and sub- regions and corresponding river types and type numbers according to German LAWA classification [51,52].

\begin{tabular}{|c|c|c|c|}
\hline Ecoregion & $\begin{array}{c}\text { Subregion } \\
\text { (Geomorphology. } \\
\text { Vegetation) }\end{array}$ & $\begin{array}{c}\text { KRB Specific River Type } \\
\text { (Bedrock. Altitude. } \\
\text { Examples of Rivers) }\end{array}$ & $\begin{array}{c}\text { Corresponding River } \\
\text { Type (Type Numbers } \\
\text { According to German } \\
\text { LAWA Classification } \\
\text { Scheme }{ }^{1} \text { ) } \\
\end{array}$ \\
\hline $\begin{array}{c}\text { Transbaikal } \\
\text { coniferous forest }\end{array}$ & $\begin{array}{l}\text { Middle mountains with } \\
\text { periglacial driven } \\
\text { morphodynamics. }\end{array}$ & $\begin{array}{l}\text { Small siliceous highland rivers } \\
\text { dominated by coarse substrate } \\
\text { (Granitoid-complex in Paleozoic } \\
\text { sedimentary rocks Elevation >1100 } \\
\text { to } 2800 \text { m a.s.l. Sugnugr, Tunkhelin) }\end{array}$ & $\begin{array}{c}\text { Type } 5 \\
\text { Small coarse substrate } \\
\text { dominated siliceous } \\
\text { highland rivers }\end{array}$ \\
\hline $\begin{array}{l}\text { Realm: Palaearctic } \\
\text { Biome: Boreal forest } \\
\text { Taiga West slopes of } \\
\text { Khentii Mts. with } \\
\text { transition to } \\
\text { the fault zone of } \\
\text { Khangai/Khentii }\end{array}$ & $\begin{array}{l}\text { flat-floored valleys } \\
\text { (coniferous forest and } \\
\text { mountain steppe with } \\
\text { transition to } \\
\text { Siberian taiga) }\end{array}$ & $\begin{array}{c}\text { Small siliceous highland rivers } \\
\text { dominated by fine substrate } \\
\text { elevation } 900 \text { to } 1100 \text { m a.s.l. } \\
\text { (Kh_Trib_1 (Mandalin Gol), } \\
\text { Kh_Trib_3 (Shivertin Gol), } \\
\text { Kh_Trib_4 (Boroo Gol), Kh_Trib_5, } \\
\text { Kh_Trib_6 (Zagdalin Gol) }\end{array}$ & $\begin{array}{c}\text { Type } 5.1 \\
\text { Small fine substrate } \\
\text { dominated siliceous } \\
\text { highland rivers }\end{array}$ \\
\hline $\begin{array}{c}\text { (Plutonites. } \\
\text { Metamorphites) } \\
\text { (Khentii Mountains) }\end{array}$ & $\begin{array}{l}\text { Narrow valley with } \\
\text { steep flanks cutting its } \\
\text { way into the basement } \\
\text { rocks. Saucer shaped } \\
\text { valleys (mixed forest, } \\
\text { mountainous steppe) }\end{array}$ & $\begin{array}{c}\text { Large gravel rich highland rivers } \\
\text { (paleozoic greywacke with intrusions } \\
\text { of granite und granodiorite) } \\
\text { Elevation } 900 \text { to } 1100 \text { m a.s.l. } \\
\text { Kharaa main river. water bodies } \\
\text { Kh_Main_1 and Kh_Main_2 }\end{array}$ & $\begin{array}{c}\text { Type } 9.2 \\
\text { Large highland rivers }\end{array}$ \\
\hline $\begin{array}{l}\text { Daurian Forest } \\
\text { steppe. Realm: } \\
\text { Palaearctic. Biome: } \\
\text { temperate grasslands } \\
\text { and shrublands; } \\
\text { Eastern foothills of }\end{array}$ & $\begin{array}{l}\text { Mountain pediments } \\
\text { and peneplains with } \\
\text { broad multiple-staged } \\
\text { fluvial terraces and } \\
\text { broad flat floored } \\
\text { valleys. mountainous } \\
\text { steppe } \\
\end{array}$ & $\begin{array}{l}\text { Small lowland rivers dominated by } \\
\text { sand (Quaternary/Holocene } \\
\text { Sediments on top of paleozoic } \\
\text { metamorphites and sedimentary } \\
\text { rocks) Kh_Trib_7, Bayangol }\end{array}$ & $\begin{array}{c}\text { Type } 14 \\
\text { Small sand-dominated } \\
\text { lowland rivers }\end{array}$ \\
\hline $\begin{array}{l}\text { mountainous area } \\
\text { (Plutonites and } \\
\text { Vulcanites. Basalt } \\
\text { domes) (Selenge } \\
\text { Orkhon mountainous } \\
\text { area) }\end{array}$ & $\begin{array}{l}\text { Low undulated } \\
\text { peneplains with alluvial } \\
\text { fans. Loess cover and } \\
\text { aeolian sand. Broad } \\
\text { loess-covered valleys. } \\
\text { transition to open } \\
\text { steppe grassland }\end{array}$ & $\begin{array}{l}\text { Mid-sized and large lowland rivers } \\
\text { dominated by sand and loam } \\
\text { (Quaternary/Holocene sediment } \\
\text { rocks with isolated vulcanite } \\
\text { deposits) elevation } 600 \text { to } 900 \\
\text { m a.s.l. Kharaa main river. water } \\
\text { bodies Kh_Main_3 und Kh_Main_4 }\end{array}$ & $\begin{array}{c}\text { Type } 15 \\
\text { Mid-sized and large } \\
\text { sand and loam } \\
\text { dominated lowland } \\
\text { rivers }\end{array}$ \\
\hline
\end{tabular}

Notes: ${ }^{\mathbf{1}}$ The river type numbers in the right column refer to the German LAWA typology [52]. 


\subsection{Surface Water Bodies as Water Management Units}

A water body is characterized by similar environmental conditions [50]. In special cases, a whole river, stream or canal can be a "water body" but in many cases, changing environmental conditions along the river course require a division into separate water bodies and the application of different reference conditions. Furthermore, also abrupt changes in the ecological status (caused for example by point source emissions) require the separation into different water bodies to achieve the desired environmental objective in the most cost-effective way. The differentiation of surface water bodies led to a subdivision of the Kharaa River main course (total length $313 \mathrm{~km}$ ) into four different water bodies. For the tributaries with a total river length of $1637 \mathrm{~km}$, seven distinct water bodies could be delineated (Figure 4, Tables 5 and 6).

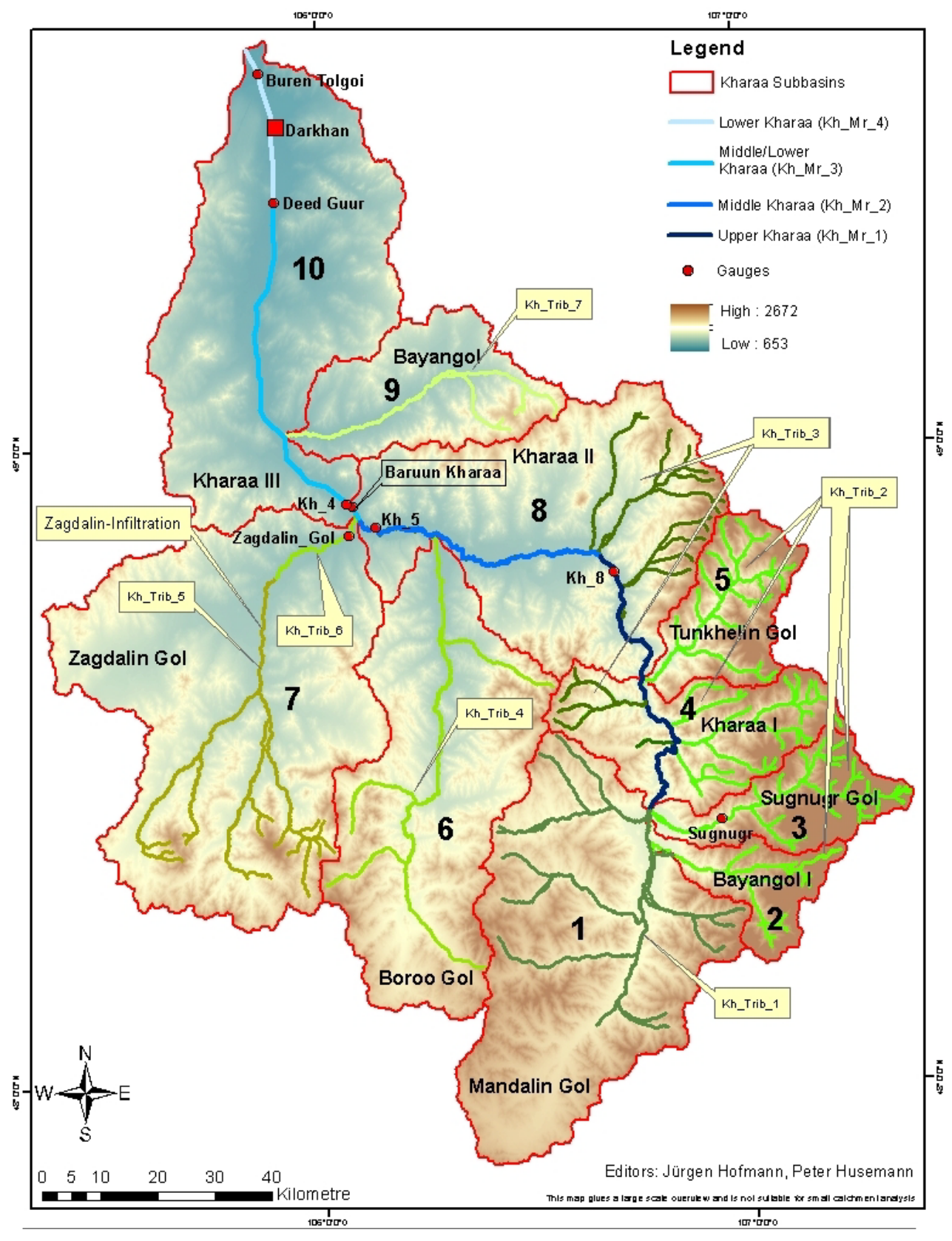

Figure 4. Description of surface water bodies, location of monitoring sites and delineation of the KRB into 10 sub-basins (No. 1-10). 
Table 5. Surface water bodies in the KRB, their description and biocoenotic regions (Figure 4). The right column "MONERIS sub-basins" refers to the description of hydrological sub-basins applied for nutrient emission modeling with MONERIS [15]. Biocoenotic

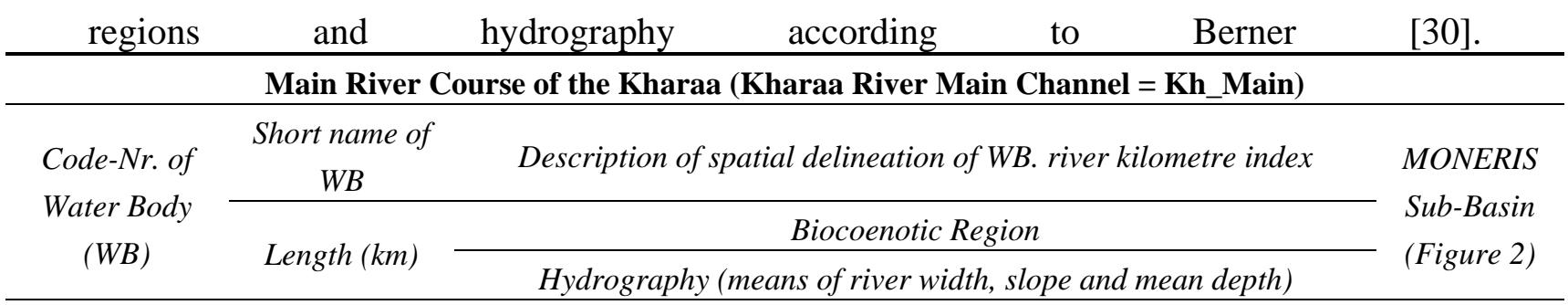

The upper Kharaa River downstream of the confluence with the

tributaries Mandlin Gol and Sugnugr Gol (ca. 7 km north of

Kh_Main_1 Upper Kharaa Batsumber), until upstream from the influent of tributary Shivertin
Gol (Kh_8) (Kharaa km 218 to Kharaa km 313)

Hyporhithral

$95 \mathrm{~km} \quad$ Width: $17-25 \mathrm{~m}$. Gradient: $3 \mathrm{~m} / \mathrm{km}$. Mean depth: 0.3 to $0.5 \mathrm{~m}$

The middle Kharaa River downstream of the tributary influent from

Middle Kharaa Shivertin Gol, until upstream of the influent from the tributary

Kh_Main_2

Zagdalin Gol (Kharaa km 159 to Kharaa km 218)

Hyporhithral

Width: 20-30 m. Gradient: $2 \mathrm{~m} / \mathrm{km}$. Mean depth: 0.4 to $0.5 \mathrm{~m}$

The middle Kharaa River downstream from the influent of the

Middle/Lower tributary Zagdalin Gol, until upstream of the Deed Guur bridge, south

Kh_Main_3 of Darkhan (Kharaa km 51 to Kharaa km 159)

8,10

$108 \mathrm{~km}$

Epipotamal

Width: $19-30 \mathrm{~m}$. Gradient: $1 \mathrm{~m} / \mathrm{km}$. Mean depth: 0.4 to $0.5 \mathrm{~m}$

The lower Kharaa River downstream of the Deed Guur bridge,

Lower Kharaa until the confluence of the Kharaa River with the Orkhon River

Kh_Main_4 (Kharaa km 0 to Kharaa km 51)

$51 \mathrm{~km}$

Epipotamal

Width: 22-38 m. Gradient: $0.7 \mathrm{~m} / \mathrm{km}$. Mean depth: 0.5 to $1.0 \mathrm{~m}$

\begin{tabular}{|c|c|c|c|}
\hline Total & $313 \mathrm{~km}$ & Total length of Kharaa main river & \\
\hline \multicolumn{4}{|c|}{ Tributaries of the Kharaa River (Kharaa River Tributaries = Kh_Trib) } \\
\hline \multirow{2}{*}{$\begin{array}{c}\text { Code-Nr. of } \\
W B\end{array}$} & $\begin{array}{c}\text { Short name of } \\
\text { WB }\end{array}$ & Description of spatial delineation of WB & \multirow{2}{*}{$\begin{array}{l}\text { MONERIS } \\
\text { Sub-Basin } \\
\text { (Figure 2) }\end{array}$} \\
\hline & Length $(\mathrm{km})$ & Biocoenotic Region & \\
\hline \multirow{2}{*}{ Kh_Trib_1 } & Mandalin & Mandalin Gol & \multirow{2}{*}{1} \\
\hline & $291 \mathrm{~km}$ & Hyporhithral with transition to Epipotamal & \\
\hline \multirow{5}{*}{ Kh_Trib_2 } & & Water body group (WBG) of the rhitral tributaries from the Khentii & \multirow{5}{*}{$2,3,4,5$} \\
\hline & WB Khentii & Mts. with natural background conditions (sub-basin 2 to 5 e.g., & \\
\hline & Reference & Bayangol-I, Sugnugr Gol, Tunkhelin, Ulgii Gol) & \\
\hline & & orographic right of the Kharaa main river course & \\
\hline & $583 \mathrm{~km}$ & Epi-. Metarhithral & \\
\hline
\end{tabular}


Table 5. Cont.

\begin{tabular}{|c|c|c|c|}
\hline \multicolumn{4}{|c|}{ Tributaries of the Kharaa River (Kharaa River Tributaries = Kh_Trib) } \\
\hline \multirow[t]{2}{*}{ Kh_Trib_3 } & $\begin{array}{l}\text { WB Khentii } \\
\text { modified }\end{array}$ & $\begin{array}{l}\text { Water body group (WBG) of the rhitral tributaries from the Khentii Mts. } \\
\text { with anthropogenic impacts. orographic left (Gatsuurt Gol, sub-basin 4) } \\
\text { and right (Shivertin Gol. sub-basin 8) of Kharaa river main course }\end{array}$ & \multirow[t]{2}{*}{4,8} \\
\hline & $221 \mathrm{~km}$ & Epi-. Metarhithral & \\
\hline \multirow{2}{*}{ Kh_Trib_4 } & Boroo & Boroo Gol & \multirow{2}{*}{6} \\
\hline & $187 \mathrm{~km}$ & Hyporhithral & \\
\hline \multirow[t]{2}{*}{ Kh_Trib_5 } & $\begin{array}{l}\text { Zagdalin } \\
\text { Upper } \\
\text { reaches }\end{array}$ & $\begin{array}{l}\text { Zagdalin Gol upstream of the Zagdalin-Infiltration } \\
\text { (subsurface flow of Zagdalin Gol) }\end{array}$ & \multirow[t]{2}{*}{7} \\
\hline & $230 \mathrm{~km}$ & Epi-. Metarhithral. transition of Hyporhithral & \\
\hline \multirow{3}{*}{ Kh_Trib_6 } & Zagdalin & & \multirow{3}{*}{7} \\
\hline & $\begin{array}{l}\text { Lower } \\
\text { reaches }\end{array}$ & Zagdalin Gol downstream of the Zagdalin-Infiltration (subsurface flow) & \\
\hline & $22 \mathrm{~km}$ & Hyporhithral & \\
\hline \multirow{2}{*}{ Kh_Trib_7 } & Bayangol & Bayangol & \multirow{2}{*}{9} \\
\hline & $103 \mathrm{~km}$ & Hyporhithral with transition to Epipotamal & \\
\hline Total & $1637 \mathrm{~km}$ & Total length of all tributaries to Kharaa & \\
\hline
\end{tabular}

Table 6. Length of river network per subbasin (Figure 2).

\begin{tabular}{|c|c|c|c|c|}
\hline \multirow{2}{*}{ Sub-Basin } & \multirow{2}{*}{ Name } & River Length per Sub-Basin (km) & \multirow{2}{*}{ Main River } & \multirow{2}{*}{ Tributary } \\
\hline & & Total Length & & \\
\hline 1 & Mandalin Gol & 281.1 & - & 281.1 \\
\hline 2 & Bayangol I & 103.7 & - & 103.7 \\
\hline 3 & Sugnugr Gol & 166.6 & - & 166.6 \\
\hline 4 & Kharaa I & 262.6 & 40.6 & 222.0 \\
\hline 5 & Tunkhelin Gol & 148.3 & - & 148.3 \\
\hline 6 & Boroo Gol & 186.7 & - & 186.7 \\
\hline 7 & Zagdalin Gol & 255.0 & - & 255.0 \\
\hline 8 & Kharaa II & 283.1 & 112.5 & 170.7 \\
\hline 9 & Bayangol & 103.3 & - & 103.3 \\
\hline 10 & Kharaa III & 160.1 & 160.1 & - \\
\hline Total & & 1950.6 & 313.2 & 1637.4 \\
\hline \multicolumn{3}{|c|}{ Total length of all water bodies } & \multicolumn{2}{|c|}{1950.6 km } \\
\hline \multicolumn{3}{|c|}{$\begin{array}{l}\text { Length of water bodies (Kh_Trib_2) with reference state } \\
\text { (percentage of water bodies in pristine conditions) }\end{array}$} & \multicolumn{2}{|c|}{$\begin{array}{c}583 \mathrm{~km} \\
30 \%\end{array}$} \\
\hline
\end{tabular}

The stream reference condition represents the natural or near natural status of a water body with respect to biotic and abiotic factors. For water quality issues the Kh_Trib_2 water body group was used as the reference for the assessment as it represents a good ecological status (GES). Compared to the total length of all surface water bodies $(1950.6 \mathrm{~km})$, it can be stated, that around 30\% (583 km) are in pristine condition. However, different colonization patterns of flora and fauna in several water bodies demanded adjustments to the reference conditions with expert knowledge during the biological assessment. 


\subsection{Observed and Monitored Pollution Patterns of Surface Waters in the KRB}

The KRB is characterized by a relatively low population density (8 to 10 people $\mathrm{km}^{2}$ ). However, spatial concentrations of population in urban settlements, an often poor state of municipal wastewater infrastructures, and high livestock densities in the riverine floodplains as well as both small and large-scale mining activities all contribute to the potential threats facing the aquatic ecosystems of the KRB. In our study, the identified key stressors affecting water quality and the aquatic ecosystem of the KRB were: (i) rising nutrient inputs; (ii) high fine sediment loads; and (iii) mining-related influxes of toxic substances [14]. Even though most rivers in Mongolia are in relatively pristine condition, a state inventory for surface water conducted in 2003 displayed that at least 23 rivers in eight provinces were morphologically changed and/or polluted due to mining activities [63], including the Kharaa-Orkhon-Selenge river system.

In recent years, the uncontrolled expansion of mining activities have continuously and/or accidentally released toxic substances into the environment causing irreversible damage [64,65]. Studies in adjoining river basins have shown that gold, copper and molybdenum mining are major polluters [23,24,65,66], drastically affecting the ecology of diatom, macroinvertebrate and fish communities [39,64]. For example, in 2007, an accident at an illegal gold mine in Khongor Sum (Darkhan-Uul Aimag) contaminated groundwater and soil with mercury, zinc and cyanide, leaving far-reaching consequences for residents and their livestock due to increased exposure of contaminated water $[40,67,68]$. Even though no impact on near-by surface waters was documented, elevated levels of heavy metals, particularly arsenic and mercury, were detected in mining ponds, the Kharaa River main channel, and its tributaries below the mining site. A longitudinal profile of arsenic concentrations in surface waters of the KRB clearly shows evidence of geogenic levels in the Khentii Mountains (including Sugnugr and Kh_Trib_2), as well as distinctly elevated concentrations downstream of gold mines, in the middle and lower reaches of the KRB (Figure 5).

Moreover, elevated levels of arsenic were found in the ash basins of the thermal power plant adjacent to Darkhan city [21,26,41]. Considering the relevant discharge data, the mass transport of toxic metals, metalloids, chloride and boron as pollution indicators was estimated at the outlet of the KRB (Figure 6).

The high loads of Fe, Mn and $\mathrm{Al}$ associated with the geogenic background of the KRB, have likely resulted from the elevated levels of these elements occurring naturally in a large portion of the basins rocks. These elements have been released by natural weathering, and leaching processes due to the operation of chemical treatments in gold mines. As arsenic is commonly associated with gold-quartz veins, the leaching process often results in increased arsenic contamination of the surrounding environment.

In regards to the nutrient concentrations in the surface waters, there was both a clear longitudinal gradient across the KRB and an increasing temporal trend identified. Nitrogen and phosphorus concentrations increased significantly along the course of the Kharaa River from 0.4 to $0.6 \mathrm{mg} \cdot \mathrm{L}^{-1}$ total $\mathrm{N}$ and 3 to $6 \mu \mathrm{g} \cdot \mathrm{L}^{-1}$ of total $\mathrm{P}$ in the headwaters to 0.7 to $0.9 \mathrm{mg} \cdot \mathrm{L}^{-1}$ total $\mathrm{N}$ and 54 to $154 \mu \mathrm{g} \cdot \mathrm{L}^{-1}$ total $\mathrm{P}$, respectively at the basin outlet (for total nitrogen (TN) see Figure 7). The highest concentrations were measured downstream of Darkhan's central wastewater treatment plant [15,18,21,35] with $1.5 \mathrm{mg} \cdot \mathrm{L}^{-1}$ total $\mathrm{N}$. The loads of orthophosphate-P at the basin outlet (Buren Tolgoi gauge) were increasing between 2007 and 2012 from 33 to $57 \mathrm{t} \cdot \mathrm{yr}^{-1}$ due to increased emissions (Figure 8). 


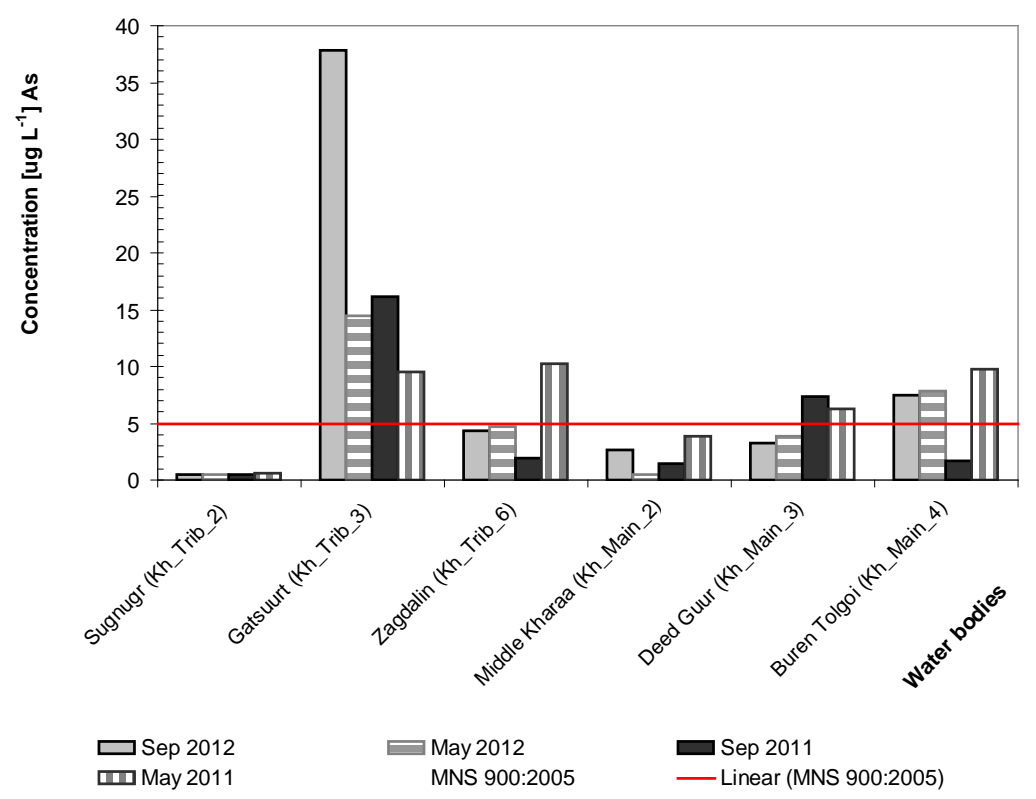

Figure 5. Concentrations of arsenic $\left(\mu \mathrm{g} \cdot \mathrm{L}^{-1}\right)$ in a longitudinal profile from the Khentii Mountains. (Sugnugr Gol, natural reference conditions) to the river basin outlet at Buren Tolgoi based on four "snapshot" sampling campaigns of surface water in May and September 2011 and 2012 (21 May 2011, 06 September 2011, 18 May 2012, 9 September 2012). The allocation of sampling sites is indicated by the code number of the individual water bodies (Table 5, Figure 3). In comparison, the acceptable maximum content of arsenic according to the Mongolian drinking water quality standards (MNS (Mongolian National Standards) 900:2005) [69] is given as a horizontal line (Monitoring data of MoMo project).

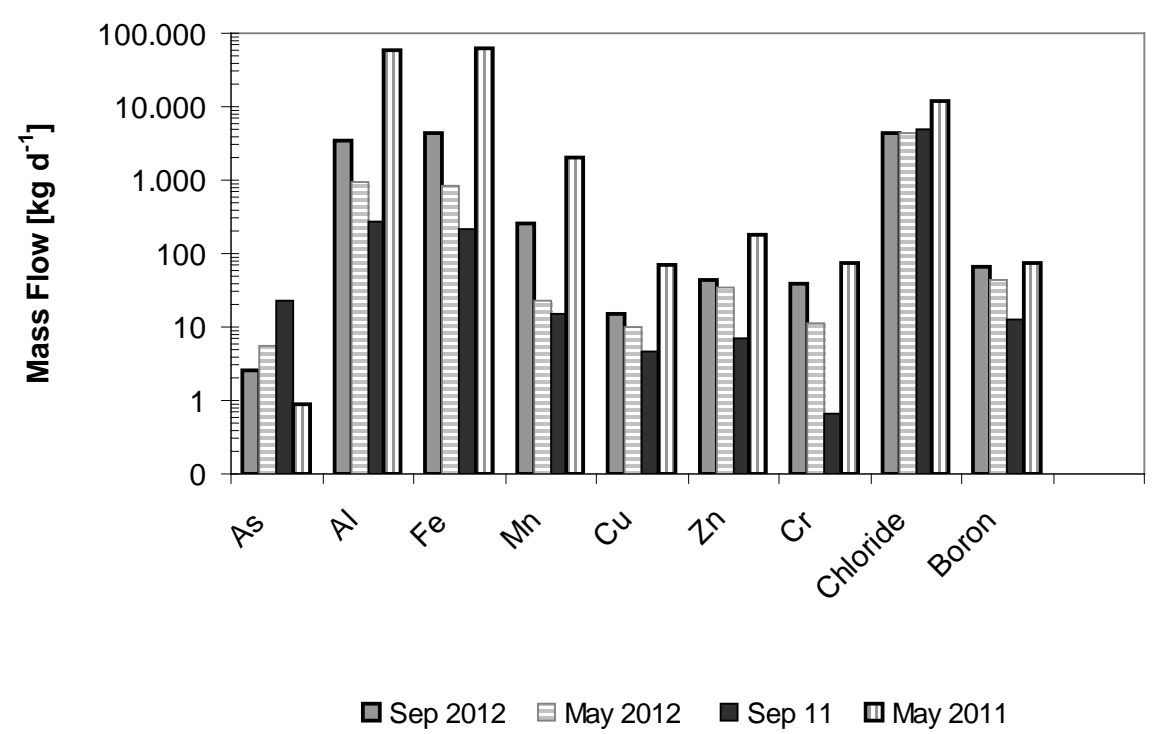

Figure 6. Mass flows $\left(\mathrm{kg} \cdot \mathrm{d}^{-1}\right)$ of heavy metals, metalloids (As, $\mathrm{Al}, \mathrm{Fe}, \mathrm{Mn}, \mathrm{Cu}, \mathrm{Zn}, \mathrm{Cr}$ ) and pollution indicators (Chloride and Boron) at Buren Tolgoi close to the KRB outlet (Lower Kharaa Kh_Main_4, Sel_Kh10_001) based on four "snapshot” sampling campaigns in May and September 2011 and 2012 (21 May 2011, 06 September 2011, 18 May 2012, 9 September 2012). For exact locations of the water body and sampling site refer to Figure 3, Tables 1 and 5. (Monitoring data of MoMo project). 


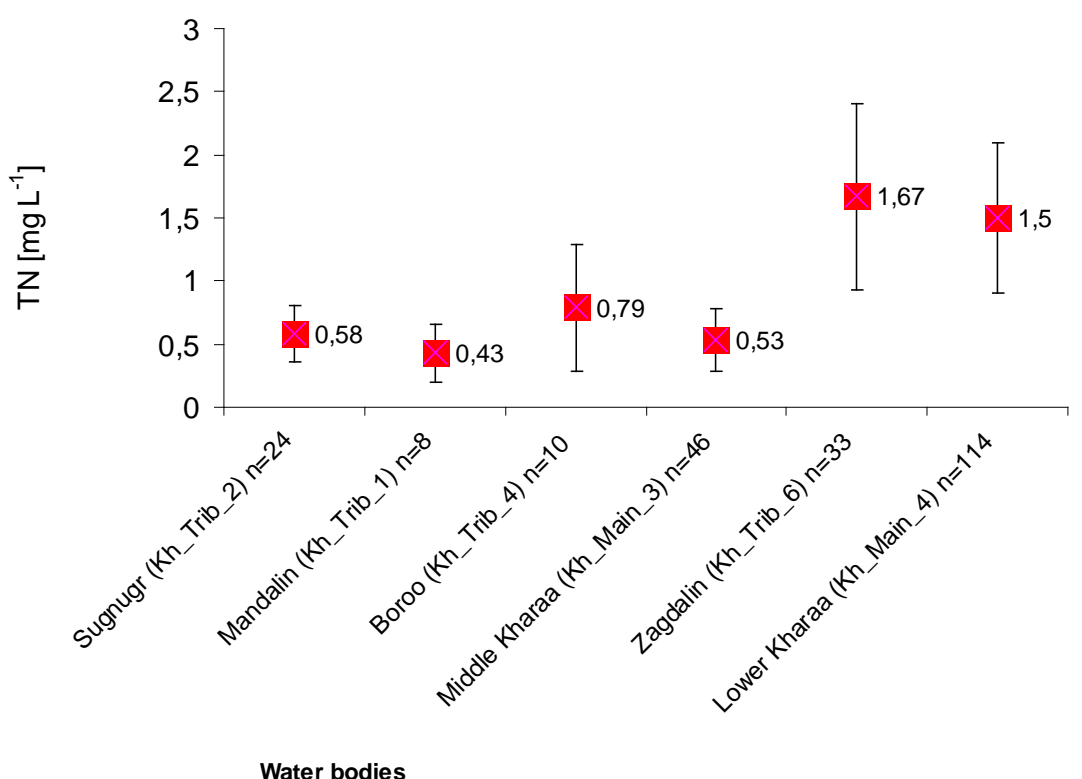

Figure 7. Concentrations of total nitrogen $(\mathrm{TN})\left(\mathrm{mg} \cdot \mathrm{L}^{-1}\right)$ in a longitudinal profile from the Khentii Mountains (Sugnugr, Kh_Trib_2, natural reference conditions) to the KRB outlet (Kh_Main_4) between 2007 and 2012. For each water body the number of analyzed water samples is indicated (n). For exact locations of the water body and sampling sites, see Figure 3, Tables 1 and 5. (Monitoring data of MoMo project).

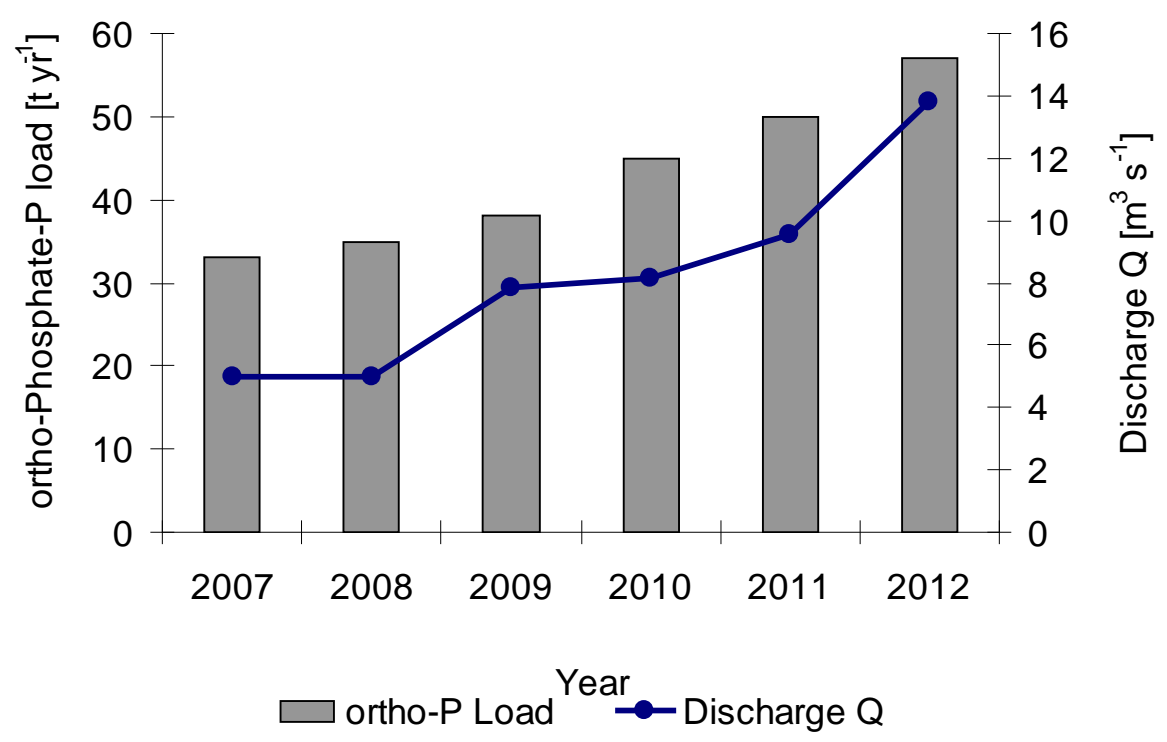

Figure 8. Loads of ortho-phosphate $\left(\mathrm{t} \cdot \mathrm{yr}^{-1}\right)$ at the KRB outlet (Lower Kharaa, Kh_Main_4, Sel_Kh10_001) for the monitoring period 2007 to 2012. The exact location of the water body and monitoring site Buren Tolgoi is given in Figure 3, Tables 1 and 5. (Monitoring data of MoMo project).

The observed total nitrogen loads in the KRB illustrate a substantial increase from 240 to $470 \mathrm{t} \mathrm{TN} \cdot \mathrm{yr}^{-1}$ indicating an increase of nutrients entering the river from diffuse sources [18]. 
Modeling results of nutrient emissions confirmed urban settlements as the main source of nitrogen and phosphorus emissions, contributing 55\% (nitrogen) and 52\% (phosphorus) of the total emissions of each nutrient [15]. As only 35\% of the total population in the river basin is connected to a WWTP, unconnected urban areas represent a key proportion of the total emissions (38\% of phosphorus and $25 \%$ of nitrogen emissions). In addition, the WWTP of Darkhan City with around 40,000 connected inhabitants was a substantial point source for nutrient influxes into the basin surface waters due to inefficient operations. According to additional modeling results, agriculture contributes 35\% of total nitrogen and 32\% of total phosphorus emissions [21], mostly through erosion from cultivated land and fallows. Moreover, sediment input caused by river bank erosion is a significant emission pathway for phosphorus [31,42].

High loads of fine sediment do not only act as a carrier of nutrients, but also constitute a major stressor themselves as sediment-induced clogging inhibits essential habitat functions of the hyporheic zones $[31,32,70]$. As a consequence, functional shifts of the macroinvertebrate community and fish fauna have already been observed [15,64]. Fine sediments are closely linked to the suspended transport of heavy metals, which is more extensive than the dissolved transport phase in the Selenge River basin [24]. Isotope-based sediment source fingerprinting techniques identified riverbank erosion (74.5\%) and surface upland erosion (21.7\%) as the main contributors to the suspended fine sediment load (grain size $<10 \mu \mathrm{m}$ ) in the catchment [31,42]. Considering that only $20 \%$ to $35 \%$ of the river bank contains riparian vegetation in the lower catchment, there is only a limited capacity to restrain eroded sediments from entering the streams. Hence, erosion abatement is considered being a major management challenge in the KRB [35]. In the future, erosion could potentially increase more than twofold in the steppe regions of the lower KRB and up to sevenfold in the forested and mountainous regions of the upper KRB due to the combined impacts of land-use and climate change [71].

\subsection{Water Quality and Ecological Assessment of Surface Water Bodies}

The previously described water quality assessment applied in Mongolia, was based on a comparison of monitoring data for chemical substances, physical parameters and MNS (4586) [69,72,73]. The derived surface water quality index (WQI) is defined as a simple expression of a more or less complex combination of several parameters (e.g., $\mathrm{NO}_{3}-\mathrm{N}$, or $\mathrm{TP}$ ), which serves as a measure for water quality [74]. This method is used to assess the ecological state of surface waters in Mongolia, which is then classified into six classes, ranging from "very good" (WQI < 0.3) to extremely polluted (WQI > 6.0). However, considering the maximum tolerable concentrations of chemical substances in MNS 4586 [72] are not derived from sound biological assessments, in relation to the impact of a given concentration to the ecological situation in a water body (e.g., TP concentration vs. Chlorophyll a concentration as expression of phytoplankton biomass), these concentrations describe more or less the threshold with an increased risk of impact to human health for a given exposure time.

Following the philosophy of the EC-WFD [50], it was proposed to identify reference conditions for undisturbed aquatic ecosystems which should be used to set standards for restoration goals. Thus a reference system with its concentration of chemical substances, its ecological state and the resulting ecological potential, represents a scientifically sound basis for the assessment of the water quality status. Impacted water bodies can then be described by $n$-fold increases of natural background conditions 
(except for $\mathrm{pH}$ and oxygen). In addition, the data logger measurements of $\mathrm{pH}$ - and oxygen amplitudes can be used as qualitative indication of eutrophication signals. The characterization of natural reference conditions was based on the Refcond Guidance [55,56] where the natural physical-chemical reference conditions of water bodies have been described with different anthropogenic indicators. These conditions were identified in the water body Kh_Trib_2 (Khentii Reference), thus representing the natural background conditions of nutrients and pollution indicators (chloride, boron and electrical conductivity; Table 7).

Table 7. Physico-chemical reference natural background conditions for the waterbody Kh_Trib_2 (Khentii reference) in comparison to the maximum tolerable concentrations of the Mongolian National Standards (MNS 900:2005, MNS 4586:1998) [69,72].

\begin{tabular}{|c|c|c|c|c|}
\hline \multirow[t]{2}{*}{ Parameter } & \multirow[t]{2}{*}{$\begin{array}{c}\text { Mongolian Drinking } \\
\text { Water Quality Standard } \\
\text { MNS 900:2005 } \\
\end{array}$} & \multirow[t]{2}{*}{$\begin{array}{c}\text { Mongolian Water } \\
\text { Quality Standard } \\
\text { MNS 4586:1998 } \\
\end{array}$} & \multicolumn{2}{|c|}{$\begin{array}{l}\text { Reference Conditions } \\
\text { (Absence of Geogenic/ } \\
\text { Anthropogenic Pollution }\end{array}$} \\
\hline & & & Arithmetic Mean & Standard Deviation \\
\hline $\begin{array}{l}\text { Electrical conductivity } \\
\qquad\left(\mu \mathrm{S} \cdot \mathrm{cm}^{-1}\right)\end{array}$ & n.i. & n.i. & 49 & 10 \\
\hline Oxygen, dissolved (\%) & n.i. & 90 & 100 & 10 \\
\hline Oxygen $\left(\mathrm{mg} \cdot \mathrm{L}^{-1}\right.$ ) & n.i. & $>9$ & 10.5 & 2.9 \\
\hline $\mathrm{pH}$ & n.i. & $6.5-8.0$ & 7 & 0.4 \\
\hline Boron $\left(\mu \mathrm{g} \cdot \mathrm{L}^{-1}\right)$ & 500 & n.i. & 10 & 12 \\
\hline Chloride (mg $\cdot \mathrm{L}^{-1}$ ) & 350 & $<50$ & 2 & 0.5 \\
\hline ТP $\left(\mu g \cdot L^{-1}\right)$ & n.i. & $<25$ & 11 & 10 \\
\hline $\operatorname{SRP}\left(\mu g \cdot L^{-1}\right)$ & n.i. & $<20$ & 5 & 1 \\
\hline $\mathrm{TN}\left(\mathrm{mg} \cdot \mathrm{L}^{-1}\right)$ & n.i. & $<0.3$ & 0.58 & 0.22 \\
\hline $\mathrm{NH}_{4}-\mathrm{N}\left(\mathrm{mg} \cdot \mathrm{L}^{-1}\right)$ & 1.5 & $<0.02$ & 0.02 & 0.01 \\
\hline $\mathrm{NO}_{3}-\mathrm{N}\left(\mathrm{mg} \cdot \mathrm{L}^{-1}\right)$ & 1 & $<1$ & 0.3 & 0.2 \\
\hline As $\left(\mu \mathrm{g} \cdot \mathrm{L}^{-1}\right)$ & 10 & n.d. & 1.8 & 1 \\
\hline $\mathrm{Hg}\left(\mu \mathrm{g} \cdot \mathrm{L}^{-1}\right)$ & 0.5 & n.d. & n.d. & n.d. \\
\hline
\end{tabular}

Notes: n.i. = no information; n.d. = not detectable, below detection limit.

While the natural reference concentrations for chloride $\left(2 \mathrm{mg} \cdot \mathrm{L}^{-1} \mathrm{Cl}\right)$ and boron $\left(10 \mu \mathrm{g} \cdot \mathrm{L}^{-1} \mathrm{~B}\right)$ ( $n=25$ for $\mathrm{Cl}$ and $\mathrm{B}$ ) in upstream water body group Kh_Trib_2 (Khentii reference) were close to or below the analytical detection range, the anthropogenic altered concentrations in the downstream water bodies Kh_Main_1 to Kh_Main_4 exceeded the natural background by a factor of 4 (boron $38 \mu \mathrm{g} \cdot \mathrm{L}^{-1}$ ) and 6 (chloride $12 \mathrm{mg} \cdot \mathrm{L}^{-1}$ ) [68].

The comparison of the three data logger stations clearly shows a gradient from the upstream regions to the middle and lower reaches in the KRB (Table 8, Supplementary Material S.2.).

The water level measurements from the three monitoring stations along the Kharaa River (Supplementary Material S.2., Figure S1a) exhibited a natural flooding regime including flood pulses and broadened flood peaks in the downstream direction (Sugnugr $>>$ Baruunkharaa $>>$ Buren Tolgoi). The gauging stations clearly reflected the increased intensity in rainfall events during the spring and summer periods resulting in prolonged flooding events during the summer months in the downstream regions (Buren Tolgoi). 
Table 8. Physical and chemical measurements (mean \pm SD) of the automatic water quality monitoring stations at Sugnugr (Khentii reference Kh_Trib_2), Baruunkharaa (Middle/Lower Kharaa. Kh_Main_3) and Buren Tolgoi (Lower Kharaa. Kh_Main_4) for the vegetation period (May to October) in 2012. For allocation of primary code ID of stations see Table 1.

\begin{tabular}{cccc}
\hline Station Primary Code ID & $\begin{array}{c}\text { Sugnugr } \\
\text { Sel_Kh03_009 }\end{array}$ & $\begin{array}{c}\text { Baruunkhaara } \\
\text { Sel_Kh10_012 }\end{array}$ & $\begin{array}{c}\text { Buren Tolgoi } \\
\text { Sel_Kh10_001 }\end{array}$ \\
\hline Temperature $\left({ }^{\circ} \mathrm{C}\right)$ & $7.1 \pm 3.9$ & $12.9 \pm 5.3$ & $14.8 \pm 6.2$ \\
Conductivity $\left(\mu \mathrm{S} \cdot \mathrm{cm}^{-1}\right)$ & $41.7 \pm 6.6$ & $250.8 \pm 63.6$ & $250.3 \pm 63.6$ \\
$\mathrm{pH}$ & $7.19 \pm 0.26$ & $8.1 \pm 0.2$ & $8.36 \pm 0.12$ \\
Oxygen saturation $(\%) *$ & $99.8 \pm 3.1$ & $95.0 \pm 9.5$ & $98.6 \pm 4.7 *$ \\
Oxygen concentration $\left(\mathrm{mg} \cdot \mathrm{L}^{-1}\right) *$ & $10.6 \pm 1.2$ & $9.3 \pm 1.4$ & $8.9 \pm 1.1 *$ \\
\hline
\end{tabular}

Note: * Oxygen measurements at station Buren Tolgoi were conducted only until mid of September 2012.

The water temperature regime of the Kharaa River was recorded during the ice free period and was predominantly shaped by strong seasonal and diurnal temperature fluctuations caused by the continental climatic conditions (Supplementary Material S.2., Figure S1b). The increased temperature at the middle and downstream stations of Baruunkharaa and Buren Tolgoi, in comparison to the upstream station (Sugnugr), was most likely caused by lower flow velocities during the summer months where increased channel width and low shading effects triggered by fragmentary riparian vegetation in these reaches increased the water temperature.

The electrical conductivity (EC) recorded in the upper region of the Kharaa River was very low, mostly below $50 \mu \mathrm{S} \cdot \mathrm{cm}^{-1}$, which further highlights the pristine water quality conditions of the upper basin (Supplementary Material S.2., Figure S1c). The EC measurements were elevated in the middle basin at Baruunkharaa station where the associated flood events caused fine sediments to be (re-) mobilized from river substrate and river banks. On the contrary, EC measurements at the lower monitoring station were decreasing during flooding events, which may be interpreted as a simple dilution effect due to more stable river morphology in this downstream area.

Considering the dependency of dissolved oxygen on water temperature, lower oxygen concentrations in the middle and the downstream regions of the KRB were expected (Supplementary Material S.2., Figure S2a). However, an increased oxygen saturation in the mid catchment station, and to a lesser extent at the downstream station, especially under low flow situations, may indicate a potentially enhanced eutrophication risk in these areas, as an increase in photosynthesis and primary production is evident (Supplementary Material S.2., Figure S2b).

In the present study, a human health perspective involving the investigation of faecal indicators and its bacteriological status were not included in the monitoring schemes. The pivotal question for the future will be whether these parameters provide essential and additional information about the river's status and its quality.

Stream biological quality indicators including the benthic invertebrate community and fish fauna investigations suggested a "good" ecological status for most river stretches in the Kharaa River basin (Tables 9 and 10). Nevertheless, the structural and functional metrics of the benthic invertebrate community indicated negative impacts in certain parts of the catchment, especially in the middle reaches of the Kharaa River main channel (water bodies Kh_Main_2 und Kh_Main_3, Figure 4), but also in certain tributaries (water bodies Kh_Trib_1, Kh_Trib_4 und Kh_Trib_6, see Table 9). 
Table 9. The ecological assessment of the Kharaa River, using the benthic invertebrate community. The table shows ecological quality metrics on a five step scale with 1 being "very good" and 5 being "bad" (EQ = Ecological quality. $\mathrm{E}=$ Ephemeroptera = mayflies. $\mathrm{P}=$ Plecoptera $=$ stoneflies $. \mathrm{T}=$ Trichoptera $=$ caddisflies $)$.

\begin{tabular}{|c|c|c|c|c|c|c|c|c|}
\hline $\begin{array}{c}\text { Water } \\
\text { Body/Sampling } \\
\text { Site } \\
\end{array}$ & $\begin{array}{c}\text { EQ of } \\
\text { Site }\end{array}$ & $\begin{array}{l}\text { EQ of } \\
\text { Water } \\
\text { Body } \\
\end{array}$ & $\begin{array}{c}\text { Total } \\
\text { Number } \\
\text { of Species } \\
\end{array}$ & $\begin{array}{c}\text { Number } \\
\text { of } \mathbf{P}\end{array}$ & $\begin{array}{c}\text { Number } \\
\text { of } E\end{array}$ & $\begin{array}{c}\text { Shannon } \\
\text { Diversity } \\
\text { Index } \\
\end{array}$ & $\begin{array}{c}\text { Share of } \\
\text { EPT } \\
\text { Individuals } \\
\end{array}$ & $\begin{array}{c}\text { Share of Fine } \\
\text { Sediment } \\
\text { Colonizers } \\
\end{array}$ \\
\hline \multicolumn{9}{|c|}{ Kharaa River main course } \\
\hline Kh_Main_1 & & 2 & & & & & & \\
\hline Kh_8.5 & 2 & & 1 & 2 & 2 & 2 & 1 & 2 \\
\hline Kh_8.3 & 2 & & 1 & 2 & 3 & 1 & 1 & 2 \\
\hline Kh_8 & 2 & & 1 & 1 & 2 & 2 & 1 & 2 \\
\hline Kh_Main_2 & & 3 & & & & & & \\
\hline Kh_7 & 2 & & 2 & 1 & 2 & 2 & 2 & 2 \\
\hline Kh_6 & 3 & & 2 & 3 & 2 & 2 & 3 & 3 \\
\hline Kh_5 & 2 & & 2 & 2 & 2 & 3 & 3 & 2 \\
\hline Kh_4 & 3 & & 2 & 2 & 3 & 3 & 2 & 2 \\
\hline Kh_3.5 & 3 & & 3 & 3 & 2 & 2 & 2 & 3 \\
\hline Kh_Main_3 & & 3 & & & & & & \\
\hline Kh_3 & 3 & & 3 & & 3 & 4 & 4 & 2 \\
\hline Kh_Main_4 & & 3 & & & & & & \\
\hline Kh_2 & 3 & & 3 & & 3 & 3 & 3 & 1 \\
\hline Kh_1 & 2 & & 3 & & 3 & 2 & 1 & 2 \\
\hline \multicolumn{9}{|c|}{ Kharaa River tributaries } \\
\hline Kh_Trib_1 & & 3 & & & & & & \\
\hline Mand_1 & 3 & & 2 & 5 & 4 & 3 & 5 & 1 \\
\hline Mand_2 & 3 & & 1 & 4 & 3 & 3 & 5 & 1 \\
\hline Kh_Trib_2 & & 2 & & & & & & \\
\hline Sug_2 & 2 & & 1 & 1 & 3 & 2 & 3 & 2 \\
\hline Sug_1 & 2 & & 2 & 1 & 3 & 2 & 3 & 2 \\
\hline Baya_1 & 2 & & 1 & 2 & 3 & 1 & 1 & 1 \\
\hline Tun_1 & 2 & & 2 & 1 & 3 & 2 & 2 & 2 \\
\hline Kh_Trib_3 & & 2 & & & & & & \\
\hline Shiv_1 & 2 & & 1 & 3 & 3 & 1 & 1 & 1 \\
\hline Kh_Trib_4 & & 3 & & & & & & \\
\hline Bor_0.5 & 3 & & 1 & 4 & 4 & 3 & 5 & 1 \\
\hline \multicolumn{9}{|l|}{ Kh_Trib_5 } \\
\hline Zagdalin upstream & \multicolumn{2}{|c|}{ no data } & & & & & & \\
\hline Kh_Trib_6 & & 4 & & & & & & \\
\hline Zag_1 & 4 & & 3 & 5 & 5 & 3 & 4 & 2 \\
\hline Kh_Trib_7 & & & & & & & & \\
\hline Bayangol2 & & & & & & & & \\
\hline
\end{tabular}


Table 10. The ecological assessment of fish fauna along sample sites in the KRB. The table shows the ecological quality metrics on a five step scale with 5 being "very good" and 1 being "bad". Note that the evaluation scale (5-1) of Table 10 are inverted compared to the evaluation scale (1-5) of Table 9 due to the applied FIBS tool [59] ("species and ecological guilds” = occurrence of river type specific species, accompanying species, migratory species, habitat guilds, reproductive guilds and trophic guilds; "abundances and ecological guilds" = relative abundance of dominant species, relative abundances of perch/roach, distribution of ecological guilds; "age structure” = relative share of $0+$ species).

\begin{tabular}{|c|c|c|c|c|c|c|c|c|}
\hline $\begin{array}{c}\text { Water } \\
\text { Body/Sampling } \\
\text { Site } \\
\end{array}$ & $\begin{array}{c}\text { EQ of } \\
\text { Site }\end{array}$ & $\begin{array}{l}\text { EQ of } \\
\text { Water } \\
\text { Body }\end{array}$ & $\begin{array}{c}\text { Species and } \\
\text { Ecological } \\
\text { Guilds } \\
\end{array}$ & $\begin{array}{c}\text { Abundances } \\
\text { and Ecological } \\
\text { Guilds } \\
\end{array}$ & $\begin{array}{c}\text { Age } \\
\text { Structure }\end{array}$ & $\begin{array}{c}\text { Migratory } \\
\text { Index }\end{array}$ & $\begin{array}{c}\text { Fish } \\
\text { Region }\end{array}$ & $\begin{array}{c}\text { Community } \\
\text { Dominance } \\
\text { Index } \\
\end{array}$ \\
\hline \multicolumn{9}{|c|}{ Kharaa River main course } \\
\hline \multicolumn{2}{|c|}{ Kh_Main_1 } & 3 & & & & & & \\
\hline Kh_8.5 & 3.13 & & 2.67 & 2.67 & 4.2 & 3 & 5 & 1 \\
\hline Kh_8 & 2.65 & & 2 & 2.33 & 4.6 & 1 & 3 & 1 \\
\hline \multicolumn{2}{|c|}{ Kh_Main_2 } & 3 & & & & & & \\
\hline Kh_7 & 3.13 & & 2.33 & 3 & 4.2 & 1 & 5 & 3 \\
\hline Kh_6 & 2.84 & & 3 & 1.83 & 4.2 & 1 & 5 & 1 \\
\hline Kh_5 & 2.93 & & 3.1 & 2.5 & 3 & 2 & 5 & 2 \\
\hline Kh_4 & 3.02 & & 3 & 2.91 & 3.2 & 2 & 5 & 2 \\
\hline \multicolumn{2}{|c|}{ Kh_Main_3 } & 2 & & & & & & \\
\hline Kh_3 & 2.15 & & 2.67 & 2.6 & 1.67 & 1 & 3 & 1 \\
\hline \multicolumn{2}{|c|}{ Kh_Main_4 } & 3 & & & & & & \\
\hline Kh_2 & 3.40 & & 3.67 & 2.6 & 5 & 1 & 3 & 3 \\
\hline Kh_1 & 2.81 & & 3 & 2.5 & 3.33 & 3 & 4 & 1 \\
\hline \multicolumn{9}{|c|}{ Kharaa River tributaries } \\
\hline \multicolumn{2}{|c|}{ Kh_Trib_1 } & 2 & & & & & & \\
\hline Mand_1 & 3.06 & & 4 & 1.91 & 4 & 1 & 5 & 1 \\
\hline Mand_2 & 2.30 & & 2.33 & 1.55 & 3 & 1 & 5 & 1 \\
\hline \multicolumn{2}{|c|}{ Kh_Trib_2 } & 3 & & & & & & \\
\hline Sug_2 & 2.66 & & 3 & 1.8 & 1.5 & 5 & 5 & 3 \\
\hline Sug_1 & 3.31 & & 3.84 & 2.5 & 3.5 & 3 & 5 & 2 \\
\hline Baya_1 & 2.91 & & 3.5 & 1.8 & 4 & 1 & 5 & 1 \\
\hline Tun_1 & 4.02 & & 3.67 & 3.4 & 4 & 5 & 5 & 5 \\
\hline \multicolumn{2}{|c|}{ Kh_Trib_3 } & 3 & & & & & & \\
\hline Shiv_1 & 2.72 & & 2.67 & 1.55 & 3 & 5 & 5 & 1 \\
\hline \multicolumn{2}{|c|}{ Kh_Trib_4 } & 3 & & & & & & \\
\hline Bor_0.5 & 3.55 & & 3.67 & 3.55 & 4 & 1 & 5 & 3 \\
\hline \multicolumn{9}{|c|}{ Kh_Trib_5 } \\
\hline \multicolumn{2}{|c|}{ Zagdalin upstream } & no data & & & & & & \\
\hline \multicolumn{2}{|c|}{ Kh_Trib_6 } & 3 & & & & & & \\
\hline Zag_1 & 3.31 & & 4 & 2.09 & 3.5 & 1 & 5 & 5 \\
\hline \multicolumn{9}{|c|}{ Kh_Trib_7 } \\
\hline Bayang & & no data & & & & & & \\
\hline
\end{tabular}


The vertical exchange of water between the river and hyporheic zone was measured by Hartwig [31,32], who found evidence for the physical clogging of the river bed in some stretches of the Kharaa River downstream from the confluence with the Zagdalin River. The physical clogging of the river bed may reduce habitat quality for benthic invertebrate species having life stages that are associated with the hyporheic zone as well as for gravel spawning fish. Analyses of the river fish fauna composition illustrated a reduced number of those species that are targeted or regularly caught by resident fishers. The taimen (Hucho taimen), an endangered salmonid, is once such species, which is all but locally extinct in the basin and is continually facing rapid population declines across all Mongolia due to increased poaching activities. Additionally, a relative reduction of larger individuals of several fish species (e.g., B. lenok and T. baicalensis) was also identified (see Table 10).

In order to successfully maintain healthy fish stocks throughout the KRB, better compliance and stricter enforcement of Mongolia's existing fishing regulations is vital. It is essential that illegal fishers are detected and prosecuted for their use of prohibited and damaging fishing gear (e.g., nets, dynamite, or triple hooks), for fishing during spring spawning closed seasons (1st of April until the 15th of June every year), and for the intentional killing of protected species. In addition, further enhancements to the fishing legislation such as minimum sizes and total take limits should also be introduced to mitigate overfishing practices and better protect these threatened fish communities and the ecological health of the river for the future. A recent survey among fishers in the KRB conducted in 2012, highlighted the fact that many local fishers could not identify fish species correctly nor were many aware of the existing regulations (Andrew Kaus, unpublished data 2012). Therefore, widespread educational campaigns and capacity development activities are urgently required to improve fisher knowledge, understanding and compliance in the Kharaa River basin.

The ecological quality of surface waters in the upstream reaches of the KRB (water body Kh_Main_1), as indicated by benthic invertebrate assessments, was classified as "very good” or "good” between 2006 and 2011. Benthic invertebrate communities were highly diverse and represented a more or less natural reference condition. The fish-based assessment using FIBS also indicated a "good" ecological condition between 2006 and 2012, denoting an un-impacted and healthy river. Human activities in these regions only moderately affected fish species richness, relative abundances and diversity of fish species.

In the middle reaches of the Kharaa River (water body Kh_Main_2) a "good” to "moderate" ecological status was determined from the assessment of benthic invertebrates, with deficits identified in the structural composition of the community especially in the lower sections. The fish community composition in the mid Kharaa River catchment indicated in general a "good ecological status" for the years 2006 to 2012. Some minor deficits were identified with regards to species abundance and the distribution of age classes and indicator indices. These deficits were attributed to increased fishing pressure in the region over recent decades. Furthermore, the assessment shifted from "good" to “moderate” between 2006 and 2012.

The middle and lower reaches of the Kharaa River (water body Kh_Main_3) were assessed in 2006 and 2007 at a single location, with structural and functional deficits in the benthic invertebrate communities identified, which in turn resulted in a "moderate" ecological status classification. The assessment of resident fish communities also suggested a "moderate” ecological status, although 
with similar deficits as described for water body Kh_Main_2. However, it must be noted that only one sampling site could be analyzed for this section of the river.

The lower reaches of the Kharaa River (water body Kh_Main_4), from close to the city of Darkhan until the confluence with the Orkhon River were assessed as being at a "good" or "moderate" ecological status. Some minor effects on ecological quality downstream from Darkhan were identified, but $20 \mathrm{~km}$ further downstream, close to the hydrological measuring station "Buren Tolgoi", these deficits were no longer observed. The unknown reference conditions for this stream type (Mid-sized and large lowland rivers dominated by sand and loam) impeded the ecological assessment which therefore was based on the creation of a reference biocoenosis with expert knowledge. The fish-based assessment indicated a "good" ecological status with some minor deficits in species abundance and the distribution of ecological guilds. The total density of individual fish was relatively low in the Kharaa River lower reaches, which may have been caused by increased fishing pressure in the region, but is also likely due to the relatively low species diversity in this river section.

The tributaries in the southernmost part of the catchment (Mandalin Gol, water body Kh_Trib_1), are characterized by a gradually declination, ground slope (around 2 per mill) with pasture farming close to the rivers. The ecological quality as indicated from macroinvertebrate assessment, during 2006/2007, was “moderate” to “poor”. By contrast, fish assemblages indicated a "moderate” ecological quality with deficits in abundance and guild distributions.

The tributaries originating in the Khentii Mountains (water bodies Kh_Trib_2) were identified as being in a natural reference state with regards to benthic invertebrates, and could be classified from 2006 to 2011 as "very good" to "good” with some seasonal variability. The fish community surveys also indicated a "very good" to "good" ecological quality of these river sections, although showed some minor restraints in age and abundance structures, as the number of species caught were slightly reduced.

Tributaries representing lower mountainous streams originating in the forelands (Shivertin Gol, water bodies Kh_Trib_3), showed a "good” ecological status based on both benthic invertebrates and fish surveys. The small stream Gatsuurtin Gol was not assessed during the sampling period.

The initial assessment of the Boroo Gol (water body Kh_Trib_4) indicated a "moderate” ecological status, with the number of EPT species strongly reduced in the benthic invertebrate samples. An increased share of potamophilous and lotic species was identified, which may have been caused by an altered hydrological regime. Additionally, green filamentous and blue-green algae were observed during the samplings, also indicating altered hydrology and increased nutrient concentrations. Nonetheless, the fish fauna assessment indicated a "good" ecological status in the Boroo River.

The lower reaches of the Zagdalin River sub-catchment (water body Kh_Trib_6), a major tributary of the Kharaa River, was assessed as being in a "moderate" or "poor" ecological status. A considerable reduction in the number of EPT species was determined, with the total number of species and individuals being also relatively low resulting in a low biodiversity index (Table 10). In contrast to these findings, the fish fauna showed only minor ecological deficits with regard to species richness and in the structure and abundances of ecological guilds.

In the water bodies of the upper Zagdalin Gol sections, (water body Kh_Trib_5) and Bayangol II (water body Kh_Trib_7), there was no ecological assessment performed. 


\subsection{Initial Risk Assessment of Surface Water Bodies in the KRB}

The results of the initial risk assessment for the surface water bodies in the KRB, following the methods detailed in Section 2.5, have been visualized below in Figure 9. Water bodies with a higher risk of failing to reach a "good" chemical status were mostly situated in the mid and lower reaches of the KRB marked in red and yellow.

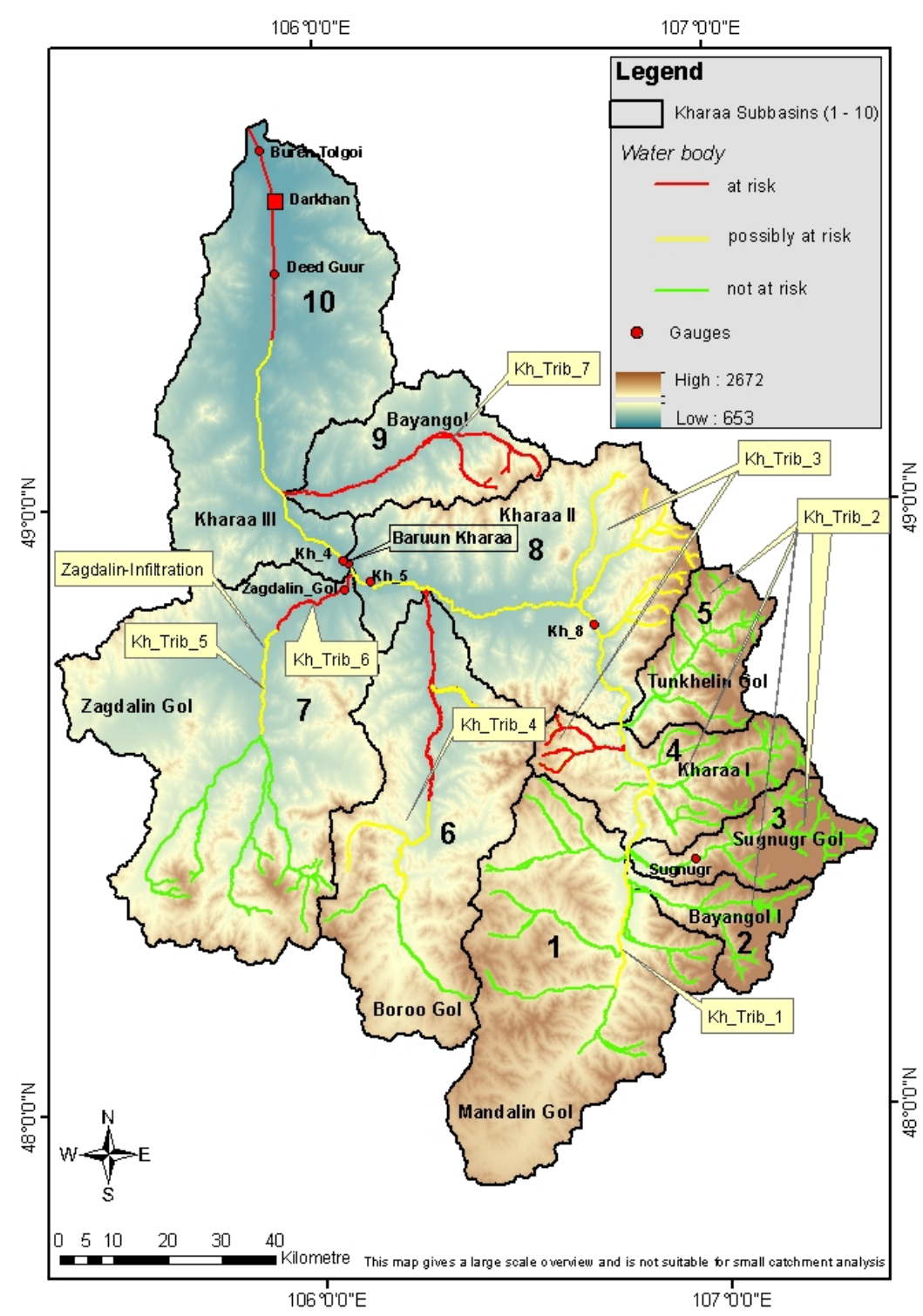

Figure 9. Initial assessment of the KRB surface water bodies, indicating the risk of failure to reach a good chemical and/or ecological status. In addition to the presented assessment with the illustrated surface water monitoring sites, the map considers data derived from other publications $[13,22,25,41,65]$.

The detailed evaluation matrix of each individual water body concerning the initial risk assessment is given in Supplementary Material S.3. Compared to EC-WFD based ecological status classifications of river basins in Central Europe with significant higher data availability [75] the presented risk assessment in the KRB can initially serve as a basis for the future sustainable management of natural water resources. 
In contrast to the findings presented here, the most recent Mongolian report on water quality in the KRB (Zandaryaa) [13] states that the "overall assessment of the chemical composition has shown good chemical conditions at the sampling sites in the Kharaa River, and there was no clear indication of nutrient pollution. Moreover, the heavy metal contamination study was only assessed with concentration of iron and chromium (VI) and the concentrations did not exceed the regulatory limits. The hydrobiological assessment based on the macroinvertebrate community within the framework of the surface water quality monitoring program in the KRB has been conducted since 2005. The analysis of the results from two monitoring sites between 2005 and 2010 indicated a good ecological status for the river" (Zandaryaa) [13]. This statement is based on five monitoring stations throughout the Kharaa River main channel (Table 1), using the Kharaa station upstream of Zuunkharaa (Sel_Kh08_004 in Table 1) as a reference site. However, the Kharaa River station upstream of Zuunkharaa does not present pristine conditions since there are several "hot spots" (e.g., gold mining in the Gatsuurtin tributary area) upstream of this station. Thus, the methods of water quality assessment (Section 3.4) and the resulting differences underline the necessity to reconsider/reinterpret the results of Zandaryaa [13] in the light of the current results.

\subsection{Stressor Complexes and Need for Action at the River Basin Level}

Environmental changes that cause certain responses in a system of interest (e.g., an ecosystem) can be described as a stressor [76]. Direct stressors can represent the immediate cause of an effect (e.g., oxygen depletion causing suffocation of fish), while indirect stressors are preceding factors, in a causal pathway conditioning an effect (e.g., river bank erosion-causing clogging of the hyporheic zone- in turn creating a response in the invertebrate community). After incorporating and evaluating all available data concerning the $\mathrm{KRB}$, eight thematic stressor complexes for the water management sector were identified:

- Insufficient provisions of safe drinking water and hygienic sanitation in ger populations (low income, peripheral settlements consisting of traditional Mongolian felt tents (ger) and/or simple, detached houses) [77];

- $\quad$ Deficient water supply and wastewater disposal systems for rural settlements [77];

- Degradation of hydrological processes in the Khentii Mountains, that are essential for the recharge of surface and groundwater resources of the entire basin [17,34,35];

- Unregulated mining activities impacting the quality and quantity of the already scarce surface water resources [26,40,41];

- Erosion of the cleared and structurally fragile river banks and the resulting high fine-grained sediment loads that are inhibiting habitat functions on the river substrate [31,32].

In general, the density of the monitoring network in the KRB for biological and chemical water quality indicators is not very high and in some regions completely lacking, so that a comprehensive assessment and stressor identification is often not possible.

Prioritizing actions is necessary in order to secure ecosystem services and sustainable utilization of water resources in the KRB. The nexus of deficits, causes and countermeasures as well as the identified 
stressor complexes provide an essential overview (Supplementary Material S.4., Tables S12 and S13). The need for protection of environmental assets can be ranked as follows:

(i) The first critical measure must involve the conservation of the KRB's “water towers”, which includes all tributaries originating from the Khentii mountains, (especially water body group Kh_Trib_2) in order to safeguard the current amount of surface water quantity $[17,78]$ and quality [15]. In addition, the mountainous water courses represent important places of reproduction, feeding and refuge for the aquatic fauna. Thus, these areas must be exempted from any exploitation, especially from mining, deforestation, overgrazing and overfishing.

(ii) The regeneration of river riparian zones must be fostered by eliminating/reducing the major pressures (e.g., livestock herding). Protecting non-degraded, remnant river riparian zones as well as areas with a high potential of self-regeneration should have the highest priority [32].

(iii) The infiltration of untreated wastewater into groundwater which is then extracted for domestic self-supply in the river riparian zones must be first identified and subsequently measures implemented to abate this practice. The installation of adapted semi-central wastewater collection and treatment technologies in combination with timber production is one option that would minimize the pressure on riparian vegetation [77].

(iv) Measures must be taken to avoid contamination from mining operations, while at the same time implementing rehabilitation measures of insecure tailing basins, such as the ash deposition sites of the thermal power plant in Darkhan.

With respect to water quality, the most relevant problems include erosion and the subsequent high fine sediment loads, the poor state of wastewater infrastructures, and the emission of toxic substances related to mining and industrial activities (Supplementary Material S.4.). Grazing pressure due to large numbers of livestock contributes to the destabilization of riverbanks, thus promoting their erosion and the influx of high fine sediment loads. Strategies to prevent river bank erosion therefore must include viable alternatives for animal grazing such as the installation of protected buffer strips and the provision of alternative drinking water sources for animals [31]. Moreover, land management practices which are better suited to the semi-arid steppe environment (e.g., mulching of croplands with wheat straw), if employed in the future could additionally help to reduce soil erosion [71].

With regard to the emission of toxic substances, a stricter enforcement of existing environmental legislation is crucial. In the recent past, water governance in Mongolia was characterized by unclear and/or overlapping competences of a wide range of institutions, limited budgets for environmental monitoring and implementing of conservation measures, as well as a lack of water experts, especially in rural areas. However, there have been substantial reforms in recent years, including the promotion of IWRM/RBM as the national strategy for sustainable management [79-85]. In the KRB, water contamination by heavy metals is typically linked to either gold mining or industrial activities including power generation. While mining activities have become more regulated in the past few years (including provisions to ban mining within $50 \mathrm{~m}$ from river banks), there is still a lack of emission control. Moreover, long lasting legacies of past emissions have led to the contamination of sediments from where toxic substances remain and continue to be released. For the KRB, unlike many other river basins of Mongolia, these hot spots of environmental contamination are documented [15,18,21], 
allowing for a more systematic surveillance and planning of rehabilitation measures. A summary of the recommended measures is given in Supplementary Material S.5., Tables S14 to S23.

\section{Conclusions}

In this paper, the presented concept of characterizing stream landscapes in northern Mongolia and delineating water bodies as water management units serves the purpose of reporting and designing river basin management plans. Using the criteria of the German river typology as a framework and taking ecoregion features into account like geology, geomorphology, vegetation and climate, five different river types were distinguished in the KRB: (i) Small siliceous highland rivers dominated by coarse substrate; (ii) Small siliceous highland rivers dominated by fine substrate; (iii) Large gravel rich highland rivers; (iv) Small lowland rivers dominated by sand; and (v) Mid-sized and large lowland rivers dominated by sand and loam. Subsequently, we divided the Kharaa River main channel into four water bodies and its tributaries into seven water bodies, with comparable biocoenotical, physical-chemical and hydrological features. This approach was regarded as useful for water resources assessments and the identification of management measures.

The Khentii Mountains in the north-east of the catchment were found to be the "water towers" of the basin and represent an undisturbed reference state without anthropogenic impacts on aquatic ecosystems. Thus, these stream reaches with its characteristically low concentrations of chemical substances and its distinguishing biocoenosis and excellent ecological status, represent a reference location that can be regarded as a scientifically sound base for the assessment of the water quality status across the KRB. The assessment of anthropogenic impacts in comparable water bodies can then be described with the $n$-fold exceeding level from natural background concentrations and can be used to set standards for restoration. This approach offers the possibility to develop new assessment tools, having a sound scientific base compared to the application of actual national standards which are lacking any bio assessment philosophy.

The initial risk assessment of the ecological and chemical status of surface waters in the KRB revealed the following picture:

(i) Most water bodies in the upper reaches are in good chemical and ecological conditions;

(ii) The impact of gold-mining, urbanization, overgrazing, logging and wild fires have had a substantial impact on the water quality in the middle and lower reaches;

(iii) Downstream of the impacted reaches there is still a remarkable potential for nutrient retention and self-cleaning processes, which are threatened without implementing protection measures.

In conclusion, the interconnection of anthropogenic pressures, ecological deficits, causes and rehabilitation/protection measures should be assessed in detail on a water body scale, in order to foster the ongoing process of designing a catchment specific river basin management plan. The example of the KRB demonstrates that RBM planning and implementation in environmentally and socioeconomically heterogeneous river basins requires more homogenous sub- units for management actions. The presented delineation of water bodies, as is common practice in the context of the EU-WFD implementation, ideally serves this purpose. 


\section{Supplementary Materials}

Supplementary materials can be accessed at: http://www.mdpi.com/2073-4441/7/7/3166/s1.

\section{Acknowledgments}

This research was financially supported by the German Ministry of Education and Research (BMBF) (BMBF project No. 03300762). Special gratitude is owed to all our Mongolian partners, employees and students for their technical and field assistance, in particular Gerel Osor (1969-2014, Mongolian University of Science and Technology, Darkhan) for conducting the regular monitoring since 2006 until 2013 even under harsh climatic conditions. Special gratitude is owed to Martin Oczipka (Faculty of Spatial Information, University of Applied Sciences Dresden, Germany) for providing the full panorama views of the investigated river landscapes in KRB (Supplementary Material S.1., [86]).

\section{Author Contributions}

Jürgen Hofmann, the first author, structured and drafted most parts and figures of the original manuscript and coordinated the work of the co-authors. Daniel Karthe drafted Sections 3.1 and 3.3 (pollution patterns of surface waters) and contributed to all sections dealing with water quality assessment (Sections 3.4 and 3.5). Ralf Ibisch and Michael Schäffer drafted Section 2.3 (biological data) and linked ecological assessments with findings on water quantity and quality (Sections 3.4 and 3.5). They also contributed to the Supplementary Materials S.1., S.3. and S.5. and helped formatting the manuscript. Michael Schäffer edited Supplementary Material S.2. Sonja Heldt contributed to Section 1.3 (water management in Mongolia), Section 3.6 (stressor complexes) and Supplementary Materials S.1., S.4. and S.5. Saulyegul Avlyush co-authored the sections dealing with water quality monitoring in KRB (Section 1.2), water management in Mongolia (Section 1.3) and translated the abstract and headings of all Tables and Figures into Mongolian language (Supplementary Material S.6.). Andrew Kaus thoroughly revised the entire manuscript and included biological information on Sections 2 and 3.

\section{Conflicts of Interest}

The authors declare no conflict of interest.

\section{References}

1. Crutzen, P.J.; Stoermer, E. The “Anthropocene”. IGBP Newsl. 2000, 41, 17-18.

2. Wilcox, P.P.; Sorice, M.G.; Young, M.H. Dryland ecohydrology in the anthropocene: Taking stock of human-ecological interactions. Geogr. Compass 2011, 5, 112-127.

3. Meybeck, M. Global analysis of river systems: From earth system controls to anthropocene syndromes. Philos. Trans. R. Soc. B Biol. Sci. 2003, 358, 1935-1955.

4. Meybeck, M.; Kummu, M.; Dürr, H.H. Global hydrobelts and hydroregions: Improved reporting scale for water-related issues? Hydrol. Earth Syst. Sci. 2013, 17, 1093-1111.

5. Messerli, B.; Viviroli, D.; Weingartner, R. Mountains of the world: Vulnerable water towers for the 21st century. Ambio 2004, 13, 29-34. 
6. Steffen, W.; Crutzen, P.J.; McNeill, J.R. The Anthropocene: Are humans now overwhelming the great forces of nature. Ambio 2007, 36, 614-621.

7. Vörösmarty, C.J.; Pahl-Wostl, C.; Bhaduri, A. Water in the Anhropocene: New perspectives for global sustainability. Curr. Opin. Environ. Sustain. 2013, 5, 535-538.

8. Schoeman, J.; Allan, C.; Finlayson, C.M. A new paradigm for water? A comparative review of integrated, adaptive and ecosystem-based water management in the Anthropocene. Int. J. Water Res. 2014, 30, 377-390.

9. Rockström, J.; Falkenmark, M.; Allan, T.; Folke, C.; Gordon, L.; Jägerskog, A.; Kummu, M.; Lannerstad, M.; Meybeck, M.; Molden, D.; et al. The unfolding water drama in the Anthropocene: Towards a resilience-based perspective on water for global sustainability. Ecohydrology 2014, 7, 1249-1261.

10. Dill, H.G.; Khishigsuren, S.; Majigsuren, Y.; Myagmarsuren, S.; Bulgamaa, J. Geomorphological studies along a transect from the taiga to the desert in Central Mongolia-Evolution of landforms in the mid-latitude continental interior as a function of climate and vegetation. J. Asian Earth Sci. 2006, 27, 241-264.

11. Törnros, T.; Menzel, L. Heading for knowledge in a data scarce river basin: Kharaa, Mongolia. In Status and Perspectives of Hydrology in Small Basins, Proceedings of the International Workshop on Status and Perspectives of Hydrology in Small Basins, Goslar-Hahnenklee, Germany, 30 March-2 April 2009; IAHS Publication Series; Herrmann, A., Schumann, S., Eds.; IAHS Publication: Wallingford, Germany, 2010; Volume 336, pp. 270-275.

12. Hilbig, W. The Vegetation of Mongolia; SPB Academic Publishing: Amsterdam, The Netherlands, 1995.

13. Zandaryaa, S. Water Quality of the Kharaa River Basin, Mongolia: Pollution Threats and Hotspots Assessment. Available online: http://iwlearn.net/iw-projects/4029/reports/water-quality-of-the-kharaariver-basin-mongolia-pollution-threats-and-hotspots-assessment (accessed on 3 February 2015).

14. Karthe, D. Needs and perspectives for investigations of water hygiene in the Kharaa River Basin, Mongolia. In Water and Environment in the Selenga-Baikal Basin: International Research Cooperation for an Ecosystem Ecoregion of Global Relevance, Proceedings of the Bringing Together Selenga Baikal Research Conference 2014, Leipzig, Germany, 1 October 2014; Karthe, D., Chalov, S., Kasimov, N., Kappas, M., Eds.; 2015, accepted.

15. Hofmann, J.; Hürdler, J.; Ibisch, R.; Schaeffer, M.; Borchardt, D. Analysis of recent nutrient emission pathways, resulting surface water quality and ecological impacts under extreme continental climate: The Kharaa River Basin (Mongolia). Int. Rev. Hydrobiol. 2011, 96, 484-519.

16. Bussien, D.; Gombojav, N.; Winkler, W.; von Quadt, A. The Mongol-Okhotsk Belt in Mongolia-An appraisal of the geodynamic development by the study of sandstone provenance and detrital zircons. Tectonophysics 2011, 510, 132-150.

17. Menzel, L.; Hofmann, J.; Ibisch, R. Studies of water and mass fluxes to provide a basis for an Integrated Water Resources Management (IWRM) in the catchment of the River Kharaa in Mongolia. Hydrol. Wasserbewirtsch. 2011, 55, 88-103.

18. Hofmann, J.; Rode, M.; Theuring, P. Recent developments in river water quality in a typical Mongolian river basin, the Kharaa case study. In Understanding Freshwater Quality Problems in a Changing World, Proceedings of IAHS-IAPSO-IASPEI Assembly, Gothenburg, Sweden, 22-26 July 2013; IAHS Publication: Wallingford, Germany, 2013; Volume 361, pp. 123-131. 
19. Priess, J.A.; Schweitzer, C.; Wimmer, F.; Batkhishig, O.; Mimler, M. The consequences of land-use change and water demands in Central Mongolia. Land Use Policy 2011, 28, 4-10.

20. Hofmann, J.; Tuul, D.; Enkhtuya, B. Agriculture in Mongolia under pressure of agronomic nutrient imbalances and food security demands: A case study of stakeholder participation for future nutrient and water resource management. In Integrated Water Resource Management: Concept, Research and Implementation; Borchardt, D., Bogardi, J., Ibisch, R., Eds.; Springer: Berlin, Germany, 2015, in press.

21. Hofmann, J.; Venohr, M.; Behrendt, H.; Opitz, D. Integrated water resources management in Central Asia: Nutrient and heavy metal emissions and their relevance for the Kharaa River Basin, Mongolia. Water Sci. Technol. 2010, 62, 353-363.

22. Brumbaugh, W.G.; Tillitt, D.E.; May, T.W.; Javzan, C.; Komov, V.T. Environmental survey in the Tuul and Orkhon River basins of north-central Mongolia, 2010: Metals and other elements in streambed sediment and floodplain soil. Environ. Monit. Assess. 2013, 185, 8991-9008.

23. Chalov, S.R.; Zavadsky, A.S.; Belozerova, E.V.; Bulacheva, M.P.; Jarsjö, J.; Thorslund, J.; Yamkhin, J. Suspended and dissolved matter fluxes in the upper Selenga River Basin: Synthesis. Geogr. Environ. Sustain. 2012, 5, 78-94.

24. Chalov, S.; Jarsjö, J.; Kasimov, N.S.; Romanchenko, A.O.; Pietrón, J.; Thorslund, J.; Promakhova, E.V. Spatio-Temporal variation of sediment transport in the Selenga River Basin, Mongolia and Russia. Environ. Earth Sci. 2015, 2, doi:10.1007/s12665-014-3106-z.

25. Inam, E.; Khantotong, S.; Kim, K.W.; Tumendemberel, B.; Erdenetsetseg, S.; Puntsag, T. Geochemical distribution of trace element concentrations in the vicinity of Boroo gold mine, Selenge Province, Mongolia. Environ. Geochem. Health 2011, 33, 57-69.

26. Batbayar, G.; Karthe, D.; von Tümpling, W.; Pfeiffer, M.; Kappas, M. Influence of urban settlement and mining activities on surface water quality in northern Mongolia. In Water and Environment in the Selenga-Baikal Basin: International Research Cooperation for an Ecosystem Ecoregion of Global Relevance, Proceedings of the Bringing Together Selenga Baikal Research Conference 2014, Leipzig, Germany, 1 October 2014; Karthe, D., Chalov, S., Kasimov, N., Kappas, M., Eds.; 2015, accepted.

27. MoMo-Consortium. Integrated Water Resources Management for Central Asia: Model Region Mongolia (MoMo): Case Study in the Kharaa River Basin; Final Project Report; Helmholtz Centre for Environmental Research: Magdeburg, Germany, 2009. Available online: http://www.iwrmmomo.de/download/MoMo\%202009_MoMo1\%20Final\%20Report.pdf (accessed on 16 June 2015)

28. Avlyush, S.; Schäffer, M.; Borchardt, D. Life cycles and habitat selection of two sympatric mayflies under extreme continental climate (River Kharaa, Mongolia). Int. Rev. Hydrobiol. 2013, 98, 141-154.

29. Avlyush, S. Life Cycles and Secondary Production of Ephemeroptera, Plecoptera, and Trichoptera (Insecta) under an Extreme Continental Climate (River Kharaa, Mongolia). Ph.D. Thesis, Faculty of Environment, Technical University of Dresden, Dresden, Germany, 2014; p. 147.

30. Berner, S. Hydromorphologische Untersuchungen an einem Fließgewässer im Norden der Mongolei (Kharaa Einzugsgebiet): Grundlagenerarbeitung für die Interpretation biologischer Daten. Master’s Thesis, University Kassel, Kassel, Germany, 2007. (In German) 
31. Hartwig, M.; Theuring, P.; Rode, M.; Borchardt, D. Suspended sediments in the Kharaa River catchment (Mongolia) and its impact on hyporheic zone functions. Environ. Earth Sci. 2012, 65, 1535-1546.

32. Hartwig, M.; Borchardt, D. Alteration of key hyporheic functions through biological and physical clogging along a nutrient and fine-sediment gradient. Ecohydrology 2014, doi:10.1002/eco.1571.

33. Heldt, S. The EU-WFD as an Implementation Tool for IWRM in non-European Countries. Master's Thesis, Faculty of Science, Radboud University Nijmegen, Nijmegen, The Netherlands; Faculty of Biology, University of Duisburg-Essen, Essen, Germany, 2014; pp. 1-169.

34. Karthe, D.; Malsy, M.; Kopp, B.; Minderlein, S.; Hülsmann, L. Assessing water availability and its drivers in the context of an integrated water resources management (IWRM): A case study from the Kharaa River Basin, Mongolia. Geoöko 2013, 34, 5-26.

35. Karthe, D.; Kasimov, N.S.; Chalov, S.; Shinkareva, G.L.; Malsy, M.; Menzel, L.; Theuring, P.; Hartwig, M.; Schweitzer, C.; Hofmann, J.; et al. Integrating multi-scale data for the assessment of water availability and quality in the Kharaa-Orkhon-Selenga River system. Geogr. Environ. Sustain. Russ. Acad. Sci. 2014, 3, 65-86.

36. Karthe, D.; Heldt, S.; Houdret, A.; Borchardt, D. IWRM in a country under rapid transition: Lessons learnt from the Kharaa River Basin, Mongolia. Environ. Earth Sci. 2015, 73, 681-695.

37. Kopp, B.; Minderlein, S.; Menzel, L. Soil moisture dynamics in a mountainous headwater area in the discontinuous permafrostz of Northern Mongolia. Arct. Antarct. Alp. Res. 2014, 46, 459-470.

38. Krätz, D. Ökologie der Fischbestände in Fließgewässern des Khentii-Gebirges (Mongolei) Bestandsaufbau, Dynamik und Gefährdung durch den Gold-Tagebau. Ph.D. Thesis, Technical University of Dresden, Dresden, Germany, 2009; p. 174.

39. Krätz, D.; Ibisch, R.; Saulyegul, A.; Ganganmurun, E.; Sonikhishig, N.; Borchardt, D. Impacts of open placer gold mining on aquatic communities in Rivers of the Khentii Mountains, North-East Mongolia. Mongol. J. Biol. Sci. 2010, 1, 41-50.

40. Hofmann, J. Bericht über die Untersuchungen von Grundwasser und Boden auf Schwermetalle und Cyanid in Khongor Sum. Project Report in German Language with Mongolian Abstract. 2008. Available online: http://www.researchgate.net/profile/J_Hofmann/publications (accessed on 8 June 2015). (In German and Mongolian)

41. Pfeiffer, M.; Batbayar, G.; Hofmann, J.; Siegfried, K.; Karthe, D.; Hahn-Tomer, J. Investigating arsenic (As) occurrence and sources in ground, surface, waste and drinking water in northern Mongolia. Environ. Earth Sci. 2015, 2, 649-662.

42. Theuring, P.; Rode, M.; Behrens, S.; Kirchner, G.; Jha, A. Identification of fluvial sediment sources in the Kharaa River catchment, Northern Mongolia. Hydrol. Process. 2013, 27, 845-856.

43. Javzan, C. Hydrochemistry of the Orkhon River Basin; Institute of Geoecology, Mongolian Academy of Sciences (MAS): Ulaanbaatar, Mongolia, 2011; p. 248. (In Mongolian)

44. Komov, V.T.; Pronin, N.M.; Mendsaikhan, B. Mercury content in muscles of fish of the Selenga River and lakes of its basin (Russia). Inland Water Biol. 2014, 7, 178-184.

45. The State Great Hural of Mongolia. Water Law of Mongolia; State Great Hural: Ulaanbaatar, Mongolia, 17 May 2012.

46. Withanachchi, S. An Analysis of Politics of Scale in Water Governance and Management in Mongolia. Master's Thesis, Faculty of Social Science, University of Kassel, Kassel, Germany, 2013. 
47. Mongolian Ministry for Environment and Green Development (MEGD). Integrated Water Management Plan of Mongolia; MEGD: Ulaanbaatar, Mongolia, 2013.

48. Mongolian Ministry for Environment and Green Development (MEGD). Integrated Water Resource Management National Assessment Report 2012; MEGD: Ulaanbaatar, Mongolia, 2012; Volumes I and II.

49. Houdret, A.; Dombrowsky, I.; Horlemann, L. The institutionalization of river basin management as politics of scale-insights from Mongolia. J. Hydrol. 2014, 519, 2392-2404.

50. European Community (EC) Directive 2000/60/EC of the European Parliament and of the Council of 23 October 2000 Establishing a Framework for Community Action in the Field of Water Policy. Available online: http://ec.europa.eu/health/endocrine_disruptors/docs/wfd_200060ec_directive_en.pdf (accessed on 9 June 2015)

51. Pottgiesser, T.; Sommerhäuser, M. Die Fließgewässertypologie Deutschlands: System der Gewässertypen und Steckbriefe zu den Referenzbedingungen. In Handbuch Angewandte Limnologie; Steinberg, C., Calmano, W., Wilken, R.-D., Klapper, H., Eds.; ecomed Verlagsgesellschaft: Landsberg/Lech, Germany 2004. (In German)

52. Pottgiesser, T.; Sommerhäuser, M. Beschreibung und Bewertung der deutschen Fließgewässertypen-Steckbriefe und Anhang. 2008. Available online: http://www.wasserblick.net/servlet/is/18727/?highlight=steckbriefe (accessed on 8 June 2015).

53. Briem, E. Gewässerlandschaften der Bundesrepublik Deutschland. ATV-DVWK Arbeitsbericht GB1; Deutsche Vereinigung für Wasserwirtschaft, Abwasser und Abfall: Hennef, Germany, 2003; pp. 1-176. (In German)

54. European Community (EC). Common Implementation Strategy for the Water Framework Directive (2000/60/EC); Guidance Document No 2: Identification of Water Bodies; EC: Luxembourg, 2003.

55. Wallin, M.; Wiederholm, T.; Johnson, R. Guidance on Establishing Reference Condition and Ecological Status Class Boundaries for Inland Surface Waters; Final Report to the European Commission from CIS Working Group 2.3, 2003. Available online: https://www.researchgate.net/profile/Richard_Johnson7/publication/240310895_Guidance_on_est ablishing_reference_conditions_and_ecological_status_class_boundaries_for_inland_surface_wat ers/links/53f1dd6d0cf2711e0c4609a7.pdf (accessed on 9 June 2015).

56. Common Implementation Strategy for the Water Framework Directive (2000/60/EC); Guidance document No. 10, River and lakes: Typology, Reference Conditions and Classification Systems. Available online: http://www.magrama.gob.es/es/agua/publicaciones/Guia10_tcm7-28996.pdf (accessed on 9 June 2015).

57. Haase, P.; Lohse, S.; Pauls, S.; Schindehütte, K.; Sundermann, A.; Hering, D. Assessing streams in Germany with benthic invertebrates: Development of a practical standardized protocol for macroinvertebrate sampling and sorting in streams. Limnologica 2004, 34, 349-365.

58. Dulmaa, A. Fish and fisheries in Mongolia. In Fish and Fisheries at Higher Altitudes: Asia; FAO Fisheries Technical Paper 385; Petr, T., Ed.; Food and Agriculture Organization of the United Nations, FAO: Rome, Italy, 1999.

59. Dußling, U.; Berg, R.; Klinger, H.; Wolter, C. Assessing the ecological status of river systems using fish assemblages. In Handbuch Angewandte Limnologie; Steinberg, C., Calmano, W., Klapper, H., Wilken, R.-D., Eds.; ecomed Verlagsgesellschaft: Landsberg/Lech, Germany, 2004; pp. 1-84. 
60. Edlund, M.B.; Soninkhishig, N.; Williams, R.M. Biodiversity of Mongolia: Checklist of diatoms including new distributional reports of 31 taxa. Nova Hedwig. 2001, 72, 59-90.

61. Landesamt für Natur, Umwelt und Verbraucherschutz Nordrhein-Westfalen (LaNUV). Gewässerstruktur in Nordrhein-Westfalen: Kartieranleitung für die Kleinen bis Großen Fließgewässer, LaNUV-Arbeitsblatt 18; LaNUV: Recklinghausen, Germany, 2012. (In German)

62. Schöll, F.; Haybach, A. Bewertung von großen Fließgewässern mittels Potamon-Typie-Index (PTI): Verfahrensbeschreibung und Anwendungsbeispiele; Mitteilung Nr. 23 der Bundesanstalt für Gewässerkunde (BfG): Koblenz, Germany, 2001; pp. 1-28. (In German)

63. Batsukh, N.; Dorjsuren, D.; Batsaikhan, G. The Water Resources, Use and Conservation in Mongolia; First National Report; National Water Committee: Ulaanbaatar, Mongolia, 2008.

64. Avlyush, S. Effects of Urface Gold Mining on Macroinvertebrate Communities: A Case Study in River Systems in the North-East of Mongolia; Lambert Academic Publishing: Saarbrücken, Germany, 2011; p. 94.

65. Thorslund, J.; Jarsjö, J.; Chalov, S.R.; Belozerova, E.V. Gold mining impact on riverine heavy metal transport in a sparsely monitored region: The upper Lake Baikal Basin case. J. Environ. Monit. 2012, 10, 2780-2792.

66. Thorslund, J.; Jarsjö, J.; Wällstedt, T.; Mörth, C.M.; Lychagin, M.Y.; Chalov, S.R. Geochemical controls on the partitioning and hydrological transport of metals in a non-acidic river system. Hydrol. Earth Syst. Sci. Discuss. 2014, 11, 9715-9758.

67. Hofmann, J.; Scharaw, B. Versorgungssituation der ländlichen Bevölkerung mit Trinkwasser und Entsorgung des Abwassers sowie Einschätzung der Gewässerbelastung mit Schwermetallen. Mong. Not. 2009, 18, 101-127. (In German)

68. Hofmann, J.; Watson, V.; Scharaw, B. Groundwater quality under stress: Contaminants in the Kharaa River basin (Mongolia). Environ. Earth Sci. 2015, 73, 629-648.

69. Safety of Environment \& Health Protection: Drinking Water Standard; MNS 900:2005; Mongolian National Center of Standardization \& Metrology: Ulaanbaatar, Mongolia, 2005.

70. Schäffer, M.; Ibisch, R.B.; Borchardt, D. Invertebrate Lebensgemeinschaften als Indikatoren für Landnutzungseffekte im Norden der Mongolei; Jahrestagung 2008 (Konstanz) Deutsche Gesellschaft für Limnologie (DGL): Hardegsen, Germany, 2008; pp. 308-312. Available online: http://www.iwrm-momo.de/download/MoMo\%20Publications.pdf (accessed on 9 June 2015). (In German)

71. Priess, J.A.; Schweitzer, C.; Batkhishig, O.; Koschitzki, T.; Wurbs, D. Impacts of agricultural land-use dynamics on erosion risks and options for land and water management in Northern Mongolia. Environ. Earth Sci. 2015, 2, 697-708.

72. Mongolian National Standard for Water Quality of the Aquatic Environment: General Requirements; MNS 4586:1998; Mongolian National Center of Standardization \& Meterology: Ulaanbaatar, Mongolia, 1998.

73. Effluent Standard, Mongolia; MNS 4943:2011; Mongolian National Center of Standardization \& Metrology: Ulaanbaatar, Mongolia, 2011.

74. Davaa, G.; Oyunbaatar, D.; Sugita, M. Surface Water of Mongolia. 2007. Available online: http://raise.suiri.tsukuba.ac.jp/new/press/youshi_sugita8.pdf (accessed on 16 February 2015). 
75. Spänhoff, B.; Dimmer, R.; Friese, H.; Harnapp, S.; Herbst, F.; Jenemann, K.; Mickel, A.; Rohde, S.; Schönherr, M.; Ziegler, K.; et al. Ecological status of rivers and streams in Saxony (Germany) according to the water framework directive and prospects of improvement. Water 2012, 4, 887-904.

76. Kolasa, J.; Pickett, S.T.A. Ecosystem stress and health: An expansion of the conceptual basis. J. Aquat. Ecosyst. Health 1992, 1, 7-13.

77. Modular concept for municipal water management in the Kharaa River Basin, Mongolia. In Integrated Water Resource Management: Concept, Research and Implementation; Ibisch, R., Kirschke, S., Stärz, C., Borchardt, D., Eds.; Helmholtz Centre for Environmental Research: Leipzig, Germany, 2015.

78. Viviroli, D.; Dürr, H.H.; Messerli, B.; Meybeck, M.; Weingartner, R. Mountains of the world, water towers for humanity: Typology, mapping, and global significance. Water Resour. Res. 2007, 43, 1-13.

79. Dombrowsky, I.; Hagemann, N.; Houdret, A. The river basin as a new scale for water governance in transition countries? A comparative study of Mongolia and Ukraine. Environ. Earth Sci. 2014. 72, 4705-4726.

80. Biswas, A.K. Integrated water resources management: Is it working? Int. J. Water Resour. Dev. 2008, 24, 5-22.

81. A Handbook for Integrated Water Resource Management in Basins; Global Water Partnership (GWP): Stockholm, Sweden, 2009.

82. Horlemann, L.; Dombrowsky, I. Institutionalising IWRM in developing and transition countries: The case of Mongolia. Environ. Earth Sci. 2012, 65, 1547-1559.

83. Mitchell, B. “Integrated Water Resources Management: A Reassessment” by Asit K. Biswas. Water Int. 2004, 29, 398-399.

84. Stalnacke, P.; Gooch, G.D. Integrated water resource management. Irrig. Drain. Syst. 2010, 24, 155-159.

85. Snellen, W.B.; Schrevel, A. IWRM: For sustainable use of water 50 years of international experiences with the concept of integrated water management. In Proceedings of the FAO/Netherlands Conference on Water for Food and Ecosystems, Wageningen, The Netherlands, 31 January-5 February 2005.

86. Monitoring from Air. Available online: https://www.htw-dresden.de/?id=20030 (accessed on 9 June 2015). Note: Within the project area "Monitoring from Air" spherical panorama views have been recorded in September 2012 by Prof. Dr. Martin Oczipka (Faculty of Spatial Information, University of Applied Sciences Dresden, Germany) and PD Dr. J. Hofmann (IGB, Berlin). Spherical panorama views of the investigated river landscapes are available online.

(C) 2015 by the authors; licensee MDPI, Basel, Switzerland. This article is an open access article distributed under the terms and conditions of the Creative Commons Attribution license (http://creativecommons.org/licenses/by/4.0/). 